\title{
Measurements of nitric oxide and ammonia soil fluxes from a wet savanna ecosystem site in West Africa during the DACCIWA field campaign
}

\author{
Federica Pacifico $^{1}$, Claire Delon ${ }^{1}$, Corinne Jambert ${ }^{1}$, Pierre Durand ${ }^{1}$, Eleanor Morris ${ }^{2}$, Mat J. Evans ${ }^{2}$, \\ Fabienne Lohou ${ }^{1}$, Solène Derrien ${ }^{1}$, Venance H. E. Donnou ${ }^{3}$, Arnaud V. Houeto ${ }^{3}$, Irene Reinares Martínez ${ }^{1}$, and \\ Pierre-Etienne Brilouet ${ }^{1}$ \\ ${ }^{1}$ Laboratoire d'Aérologie, University of Toulouse, CNRS, UPS, Toulouse, 31400, France \\ ${ }^{2}$ Wolfson Atmospheric Chemistry Laboratories, Department of Chemistry, University of York, York, YO10 5DD, UK \\ ${ }^{3}$ Laboratoire de Physique du Rayonnement, Université d'Abomey-Calavi, Cotonou, 01 BP 526, Benin
}

Correspondence: Claire Delon (claire.delon@aero.obs-mip.fr)

Received: 18 December 2017 - Discussion started: 20 March 2018

Revised: 1 February 2019 - Accepted: 6 February 2019 - Published: 21 February 2019

\begin{abstract}
Biogenic fluxes from soil at a local and regional scale are crucial to study air pollution and climate. Here we present field measurements of soil fluxes of nitric oxide (NO) and ammonia $\left(\mathrm{NH}_{3}\right)$ observed over four different land cover types, i.e. bare soil, grassland, maize field, and forest, at an inland rural site in Benin, West Africa, during the DACCIWA field campaign in June and July 2016. At the regional scale, urbanization and a massive growth in population in West Africa have been causing a strong increase in anthropogenic emissions. Anthropogenic pollutants are transported inland and northward from the megacities located on the coast, where the reaction with biogenic emissions may lead to enhanced ozone production outside urban areas, as well as secondary organic aerosol formation, with detrimental effects on humans, animals, natural vegetation, and crops. We observe NO fluxes up to $48.05 \mathrm{ngN} \mathrm{m}^{-2} \mathrm{~s}^{-1}$. NO fluxes averaged over all land cover types are $4.79 \pm$ $5.59 \mathrm{ngN} \mathrm{m}^{-2} \mathrm{~s}^{-1}$, and maximum soil emissions of $\mathrm{NO}$ are recorded over bare soil. $\mathrm{NH}_{3}$ is dominated by deposition for all land cover types. $\mathrm{NH}_{3}$ fluxes range between -6.59 and $4.96 \mathrm{ngN} \mathrm{m}^{-2} \mathrm{~s}^{-1}$. $\mathrm{NH}_{3}$ fluxes averaged over all land cover types are $-0.91 \pm 1.27 \mathrm{ngN} \mathrm{m}^{-2} \mathrm{~s}^{-1}$, and maximum $\mathrm{NH}_{3}$ deposition is measured over bare soil. The observations show high spatial variability even for the same soil type, same day, and same meteorological conditions. We compare point daytime average measurements of $\mathrm{NO}$ emissions recorded during the field campaign with those simulated by GEOS-Chem (Goddard Earth Observing System Chemistry Model) for the
\end{abstract}

same site and find good agreement. In an attempt to quantify $\mathrm{NO}$ emissions at the regional and national scale, we also provide a tentative estimate of total $\mathrm{NO}$ emissions for the entire country of Benin for the month of July using two distinct methods: upscaling point measurements and using the GEOS-Chem model. The two methods give similar results: $1.17 \pm 0.6$ and $1.44 \mathrm{GgN}$ month ${ }^{-1}$, respectively. Total $\mathrm{NH}_{3}$ deposition estimated by upscaling point measurements for the month of July is $0.21 \mathrm{GgN}$ month $^{-1}$.

\section{Introduction}

Biogenic soil fluxes of nitric oxide $(\mathrm{NO})$ and ammonia $\left(\mathrm{NH}_{3}\right)$ play an important role in tropospheric chemistry. Nitric oxide emitted by soil influences the concentration of nitrogen oxides $\left(\mathrm{NO}_{x}\right)$ in the atmosphere, consequently modifying the rates of ozone $\left(\mathrm{O}_{3}\right)$ production, where $\mathrm{O}_{3}$ is a pollutant harmful to humans and plants and also a greenhouse gas (Steinkamp et al., 2009). The production and consumption of NO in soil is regulated by microbial activity, mainly nitrification-denitrification processes, and chemical reactions (Pilegaard, 2013). Measurements using soil chambers in the field and laboratory experiments show that nitrification-denitrification, and consequently $\mathrm{NO}$ emissions, vary greatly with climate and soil conditions; in particular, they are strongly correlated with nitrogen $(\mathrm{N})$ availability, 
temperature, and soil moisture, making soil NO emissions dependent on regional temperature and precipitation patterns and fertilizer management practices (e.g. Bouwman et al., 2002; Meixner and Yang, 2006; Hudman et al., 2010).

Soil NO emissions are about $20 \%$ of total NO sources to the atmosphere (IPCC, 2007) and almost of the same order of magnitude as fossil fuel NO emissions. The soil emission of biogenic NO plays a prominent role in the regional atmospheric chemistry of non-urbanized areas, where anthropogenic emissions are negligible (Pilegaard, 2013). The main inputs of $\mathrm{N}$ compounds onto semi-arid uncultivated soils, like savanna ecosystems, are biological nitrogen fixation, atmospheric wet and dry deposition, and lightning. NO fluxes are considered as one way only, even if NO deposition exists in very specific conditions (Grote et al., 2009).

Soil $\mathrm{N}$ losses towards the atmosphere also involve $\mathrm{NH}_{3}$. The largest sources of $\mathrm{NH}_{3}$ emissions are animal husbandry and agriculture via the application of synthetic fertilizer. When released into the atmosphere, $\mathrm{NH}_{3}$ increases the level of air pollution. In the atmosphere $\mathrm{NH}_{3}$ has a relatively short lifetime of less than 5 days and high deposition rates; it is converted into ammonium $\left(\mathrm{NH}_{4}^{+}\right)$aerosols, which has a lifetime of the order of 15 days, can travel long distances, and is relevant for air quality and climate (Fuzzi et al., 2015). The exchange of soil $\mathrm{NH}_{3}$ is bidirectional as it also includes deposition. $\mathrm{NH}_{3}$ returned to the surface by deposition can potentially cause eutrophication, reducing biodiversity and water quality (Sutton et al., 2009a).

The net flux of $\mathrm{NH}_{3}$ is the combination of different exchange pathways between plant (cuticle and stomata), soil, leaf litter, and atmosphere. The overall $\mathrm{NH}_{3}$ flux for a given surface may switch from net emission to net deposition at sub-hourly, diurnal, and seasonal scales. Moreover, $\mathrm{NH}_{3}$ can be rapidly deposited onto cuticles due to its high solubility (e.g. Sutton et al., 2009b; Massad et al., 2010; Loubet et al., 2012).

The direction and magnitude of $\mathrm{NH}_{3}$ exchanges depend on the difference in $\mathrm{NH}_{3}$ concentration between the canopy and the atmosphere and on a large range of environmental factors, in particular air humidity, which influences surface wetness, and soil moisture conditions, but also vegetation cover and soil characteristics. The relationships between NO and $\mathrm{NH}_{3}$ soil fluxes have been identified through the ammonium content in the soil (McCalley and Sparks, 2008). Ammonia is mainly emitted by agricultural activities and also by the decomposition of litter and volatilization of animal excreta (Sutton et al., 2009b; Massad et al., 2010).

Soil fluxes in West Africa have only been measured in a limited number of studies due to the challenging experimental conditions (remote sites, no power supply, very hot temperatures) and mainly with manual chamber techniques rather than more complex micrometeorological techniques (Serça et al., 1998; Le Roux et al., 1995 for NO, Delon et al., 2017 for $\mathrm{NO}$ and $\mathrm{NH}_{3}$ ). However, tropical savanna has been recognized as one of the ecosystems characterized by the largest NO emissions (Davidson and Kingerlee, 1997; Hudman et al., 2012).

Anthropogenic emissions of pollutants from megacities located on the Guinean coast in southwest Africa have been increasing, and are likely to keep increasing in the next decades, due to strong anthropogenic pressure, land use change, and urbanization. When transported northward on the African continent, polluted air masses meet biogenic emissions from rural areas, which contributes to increased $\mathrm{O}_{3}$ and secondary organic aerosol production, high temperature, and solar radiation conditions highly favourable to enhance photochemistry (Knippertz et al., 2015a, b).

The objectives of this study are to quantify soil fluxes of $\mathrm{NO}$ and $\mathrm{NH}_{3}$ for the different land cover types typical of rural West Africa, suggest a tentative strategy to scale point measurements in the field to ecosystem and larger regional scale, and provide data for inventories and model evaluation to improve air quality and climate modelling.

In this paper we present soil fluxes of $\mathrm{NO}$ and $\mathrm{NH}_{3}$ measured in a rural site near the city of Savè, Benin, West Africa, during the DACCIWA (Dynamics-AerosolChemistry-Cloud Interactions in West Africa) field campaign, which lasted from 14 June to 30 July 2016 (wet season). The DACCIWA campaign was led to investigate the possible role of local air pollution in climate change in West Africa, focusing on atmospheric composition, air pollution, and cloud-aerosol interactions over several sites in the region (Knippertz et al., 2015a, b, 2017). The Savè site is part of the savanna ecosystem, where grassland is intercut with crops and degraded forest. Biogenic soil flux measurements were taken using the manual chamber technique, which is robust with reduced costs (Delon et al., 2017). Along with these observations we also present measurements of soil characteristics and meteorological variables from the same site. We include the comparison of measured NO soil emissions with those simulated by the Hudman et al. (2012) process-based model for NO soil emission implemented into GEOS-Chem.

\section{Material and methods}

\subsection{Site description}

The Savè site for ground-based observations is located in a hinterland area of Benin, $6 \mathrm{~km}$ southwest from the city of Savè $\left(8^{\circ} 02^{\prime} 03^{\prime \prime} \mathrm{N}, 2^{\circ} 29^{\prime} 11^{\prime \prime} \mathrm{E} ; 166 \mathrm{~m}\right.$ a.s.1.). The Savè ground-based observation site is located within the Gobè site managed by the Institut National des Recherches Agricoles du Bénin (INRAB).

The site is characterized by a wet savanna ecosystem. The climate of the region is Sudano-Guinean, with a rainy season from March to October and a dry season from November to February (Michiels et al., 2000). The average annual rainfall is about $1100 \mathrm{~mm}$ (Savè weather station, data averaged from 1969 to 2004; Michiels et al., 2000 and Säidou et al., 2004) 

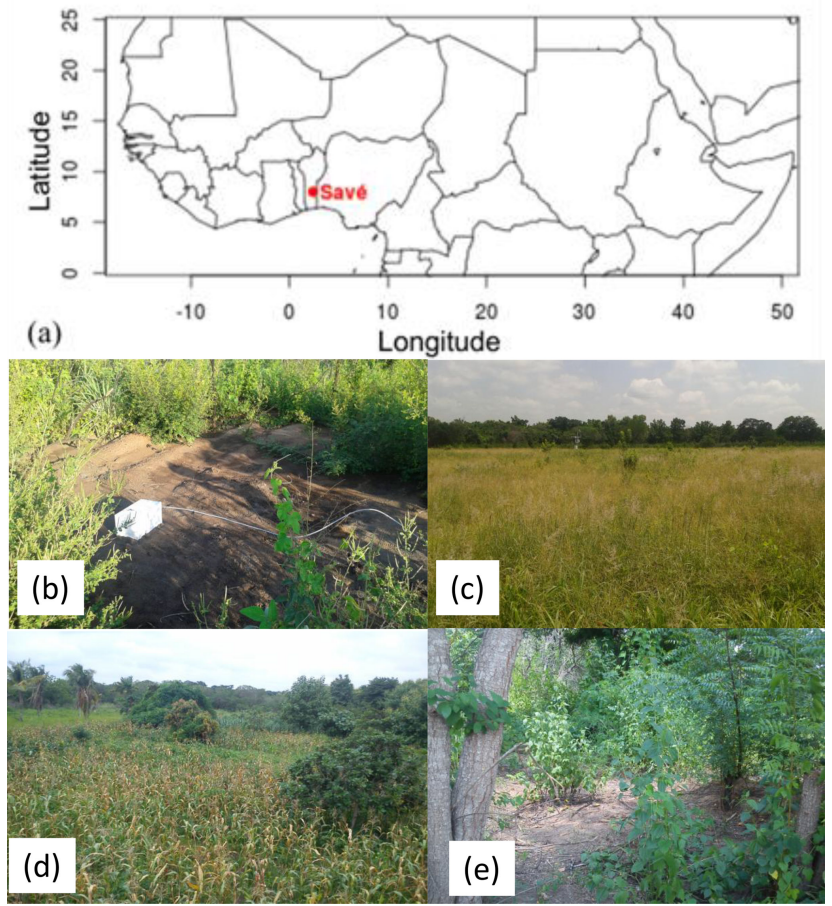

Figure 1. (a) Location of the Savè site in West Africa, (b) one of the bare soil sampling sites, (c) the grassland sampling site, (d) the maize field sampling site, and (e) the forest sampling site at the Savè site.

and the average yearly temperature is about $27.5^{\circ} \mathrm{C}$ with little variation from year to year (data averaged from 1984 to 2004; Säidou et al., 2004). Average minimum temperature, based on $1969-1990$ data, is $21.5^{\circ} \mathrm{C}$ and mean maximum temperature is $35.5^{\circ} \mathrm{C}$.

The tree coverage in the Savè region is low with most of the land occupied by subsistence agriculture and grassland (CILSS, 2016). Four land cover types are identified at the observation site: bare soil, grassland, maize field, and degraded forest. Bare soil is defined as a patch of land a minimum of $5 \mathrm{~m} \times 5 \mathrm{~m}$ wide, without vegetation growing or hanging over the plot. Ground photographs of the four land cover types are shown in Fig. 1.

The most abundant tree species next to the grassland site and in the forest are Anacardium occidentale, Daniellia oliveri, and Pterocarpus erinaceus, while the most abundant tree species next to the maize field are Mangifera indica, Cocos nucifera, Carica papaya L., Tectona grandis, and Azadirachta indica. The herbaceous vegetation is dominated by Cleome sp., Crotalaria sp., Mucuna sp., Imperata cylindrica, and Rhynchelytrum repens next to the grassland site and in the forest, with Commelina benghalensis, Euphorbia sp., Boerhavia diffusa, Phyllanthus amarus, and Digitaria horizontalis dominant by the maize field. In the maize field, the main species, Zea mays, is intercropped with Sesamum indicum and, to a lesser extent, with other species: Dioscorea
Table 1. Main characteristics of the Savè site.

\begin{tabular}{lr}
\hline & $\begin{array}{r}\text { Savè ground-based } \\
\text { observation site }\end{array}$ \\
\hline Location & $8^{\circ} 02^{\prime} 03^{\prime \prime} \mathrm{N}, 2^{\circ} 29^{\prime} 11^{\prime \prime} \mathrm{E}$ \\
Elevation & $166 \mathrm{~m}$ a.s.l. \\
Mean annual precipitation & $1100 \mathrm{~mm}$ \\
Mean annual temperature & $27.5^{\circ} \mathrm{C}$ \\
Soil type & sandy \\
Sand percentage & $87 \%$ \\
Clay percentage & $4.1 \%$ \\
\hline
\end{tabular}

sp., Manihot esculenta, Arachis hypogaea, Vigna unguiculata, Gossypium sp., Sorghum sp., and Solanum lycopersicum. The maize field was not treated with mineral fertilizer. The only livestock are a few dozen domestic fowls belonging to small subsistence-oriented family farms, mainly grazing in the maize field.

At the Savè site, the soil is sandy, with $87 \%$ sand and $4.1 \%$ clay (the rest being silt) for the $0-5 \mathrm{~cm}$ horizon. Surface $\mathrm{pH}$ ranges from 6.32 to 8.46 , depending on the location where the measurement is carried out. Mean meteorological and average soil characteristics for the observation site are reported in Table 1, and dominant vegetation species and soil composition for each land cover type are given in Tables 2 and 3, respectively. Sunrise and sunset (UTC) at the beginning and at the end of the campaign were at 05:33 and 18:08 on 14 June and $05: 42$ and 18:11 on 30 July.

\subsection{Sampling sites}

The samples were taken from the four land cover types (bare soil, grassland, maize field, and forest) at one location per day. Two to three sampling spots were chosen each day for each location, resulting in 8 to 25 measurements collected for both $\mathrm{NO}$ and $\mathrm{NH}_{3}$ soil fluxes each day. Each location was sampled during daytime from approximately 07:00 to 18:00 LT, alternating measurements at the four different land cover types from one day to the other, over the entire campaign. Bare soil and the maize field were sampled for both $\mathrm{NO}$ and $\mathrm{NH}_{3}$ soil fluxes on eight different, generally nonconsecutive days, grassland on ten days, and the forest site on four different days.

\subsection{Chamber flux measurements}

The technique used to measure $\mathrm{NO}$ and $\mathrm{NH}_{3}$ soil fluxes makes use of a Thermo Scientific 17i (Thermo Fisher Scientific, MA, USA). This analyser uses a chemiluminescence detector for NO. The air sample enters the reaction chamber and reacts with the $\mathrm{O}_{3}$ generated by an internal generator. This reaction produces luminescent radiation directly proportional to the NO concentration. The air sample is sequentially drawn through a molybdenum converter heated to $325^{\circ} \mathrm{C}$, 
which measures $\mathrm{NO}_{x}\left(\mathrm{NO}+\mathrm{NO}_{2}\right)$ by converting $\mathrm{NO}_{2}$ to $\mathrm{NO}$, and a stainless-steel converter heated to $750^{\circ} \mathrm{C}$, which measures total $\mathrm{N}\left(\mathrm{NH}_{3}+\mathrm{NO}_{x}\right)$ by converting $\mathrm{NH}_{3}$ and $\mathrm{NO}_{2}$ to NO. The detector hence measures rNO, then $r\left(\mathrm{NO}+\alpha \mathrm{NO}_{2}\right)$, and finally $r\left(\mathrm{NO}+\beta \mathrm{NO}_{2}+\gamma \mathrm{NH}_{3}\right)$, where $r$ is the $\mathrm{NO}$ detection efficiency, $\alpha$ and $\beta$ are the $\mathrm{NO}_{2}$ conversion efficiency of the molybdenum and stainless-steel converters, and $\gamma$ is the $\mathrm{NH}_{3}$ conversion efficiency of the stainless-steel converter. The efficiencies are determined by the calibration procedure. $\mathrm{NH}_{3}$ concentration is therefore calculated from total $\mathrm{N}$ minus $\mathrm{NO}_{x}$. The closed dynamic chamber technique is used to calculate fluxes. The details of this technique are fully described in Delon et al. (2017).

The remoteness of the study site limited the installation of permanent structures and we were unable to automate our chamber measurements; thus, all measurements were made manually. The instrument was powered by a generator (> $100 \mathrm{~m}$ away) and carried around on a wheeled table to reach the locations of the four soil types for which the NO and $\mathrm{NH}_{3}$ soil fluxes were measured. The analyser was connected via a Teflon tube to the Teflon chamber, which was put on the ground to detect the fluxes. The external sides of the chamber were covered with sand or soil to insulate it during the measurement. The soil under the chamber was left unperturbed. Adjustments were made in order to make sure the analyser did not reach temperatures that would invalidate the measurements.

The calibration of the NO sensor of the $17 \mathrm{i}$ analyser was made before and after the campaign, with a reference NO air mixture, i.e. $\mathrm{NO}$ in $\mathrm{N}_{2}$ diluted with zero air. The NO detection efficiency variation was $8 \%$ between the two calibrations (from 1.040 to 0.962 ). Two post-campaign calibrations were made: the first one to validate the efficiency of the $\mathrm{NO}_{2}$ converter using a reference dilution of $\mathrm{NO}_{2}$ in zero air, and the second one to validate the efficiency of the $\mathrm{NH}_{3}$ converter with a $\mathrm{NH}_{3} / \mathrm{N}_{2}$ mixture diluted in pure air (ALPHAGAZ 1, Air Liquide). No change in the $\mathrm{NO}_{2}$ conversion efficiency was necessary, and the $\mathrm{NH}_{3}$ conversion efficiency variation was $3 \%$ (from 0.963 to 0.995 ). No drift in the conversion efficiencies was observed over time; from the first calibration when the analyser was new until the postcampaign calibration, changes never exceeded $\pm 3 \%$. The zero air for $\mathrm{NO}$ and $\mathrm{NO}_{2}$ calibration was obtained by filtering ambient air previously passed on charcoal and desiccant cartridges. The dilution for all the calibration experiments was made with the 146i module (Thermo Fisher Scientific, MA, USA) and the dilution module, equipped with certified mass flow meters, on-board the ATR-42 research aircraft during an inter-calibration with other $\mathrm{NO}_{x}$ instrumentation for the DACCIWA campaign (i.e. the instrumentation on the Savè measurement site tower and the instrumentation on the ATR42 aircraft; Brito et al., 2018; Derrien et al., 2016). Reference $\mathrm{NO}$ and $\mathrm{NO}_{2}$ were ISO 6141:2015 certified at 8.73 and $8.58 \mathrm{ppm}$ for NO before and after the campaign, respectively, and $9.28 \mathrm{ppm}$ for $\mathrm{NO}_{2}$, both with $5 \%$ precision. The reference $\mathrm{NH}_{3}$ mixture was certified at $14.78 \mathrm{ppm}$ with $2 \%$ precision for $\mathrm{NH}_{3}$. Multipoint (at least four points) calibrations between 50 and $250 \mathrm{ppb}$ were done to ensure the linearity of the response, obtaining regression coefficients over 0.9993 for both $\mathrm{NO}$ and $\mathrm{NO}_{2}$. The dilution uncertainty was $10 \%$ for $\mathrm{NO}, 11 \%$ for $\mathrm{NO}_{2}$, and $13 \%$ for $\mathrm{NH}_{3}$ (see Appendix A for more detail). A multipoint calibration was done for $\mathrm{NH}_{3}$ between 30 and $200 \mathrm{ppb}$ and the regression coefficient was 0.997 . The linearity of the response for low concentrations is tested by the response to zero air calibration, giving $R^{2}=0.997$. However, at low mixing ratios (typically less than $100 \mathrm{ppb}$ ), a non-linear increase in the interactions of $\mathrm{NH}_{3}$ with the surface used in the inlet design has to be considered (Ellis et al., 2010; Whitehead et al., 2008). Therefore, an uncertainty in the quantification of low $\mathrm{NH}_{3}$ concentrations has to be taken into account due to surface interactions. The global precision of the analyser is $\pm 0.4 \mathrm{ppb}$ according to the manufacturer's specification for a $0-500 \mathrm{ppbv}$ range.

The external volume of the chamber was $40 \times 20 \times 20 \mathrm{~cm}$. The internal volume was $18 \times 38 \times 18 \mathrm{~cm}^{3}$ due to the thickness of the Teflon walls. The air inlet is located on one side of the chamber, where a small vent $4 \mathrm{~mm}$ in diameter provided pressure equilibrium between the inside and outside of the chamber. The air outlet on the other side is connected to the analyser with a $4 \mathrm{~m}$ Teflon tube (see picture displayed in Appendix B) The chamber is continuously swept with an airflow of $0.7 \mathrm{~L} \mathrm{~min}^{-1}$ ensured by the instrument pump, and the airflow is controlled inside the analyser by a flow meter. The air residence time in the chamber is approximately $20 \mathrm{~min}$ (volume / flow), and the chamber is maintained in place for $10 \mathrm{~min}$. The Teflon chamber was cleaned (with a dry, clean paper cloth) at the beginning of each day of measurement and during the day when the deposition of sand could potentially interfere with the measurements. Laboratory tests using different papers for cleaning are displayed in Appendix C. According to these results, no clear tendency for potential adsorption or desorption of $\mathrm{NH}_{3}$ arises but these tests may be useful to warn against potential pollution inside the chamber due to cleaning, which would interfere with low fluxes.

The opaque walls minimize photochemical reactions inside the chamber, which are therefore considered negligible. The chamber is placed on the soil for $10 \mathrm{~min}$. After $10 \mathrm{~min}$, the chamber is turned over to let the analyser be swept by ambient air for $5 \mathrm{~min}$, then the chamber is placed on the soil again to begin a new cycle.

The calculation of the fluxes is based on the closed dynamic chamber technique, with the following assumptions: the concentration in the chamber is equal to the concentration leaving the chamber to the analyser, and potential deposition onto the Teflon walls of the chamber is assessed but considered negligible. Vaittinen et al. (2013, and references therein) have demonstrated that the adsorption of ammonia on Teflon is negligible; however, the high $\mathrm{NH}_{3}$ mixing ratios and the controlled conditions in the Vaittinen experiment do not correspond to our field conditions. Therefore, 
experimental tests with and without the Teflon chamber attached to the analyser were made in ambient air to verify that deposition on the walls of the Teflon chamber is negligible. These tests have been made in conditions comparable to in situ measurements, i.e. temperature $\left(25\right.$ to $\left.29^{\circ} \mathrm{C}\right)$ and humidity ( $46 \%$ to $54 \%$ ), as well as $\mathrm{NH}_{3}$ concentrations (8 to $35 \mathrm{ppb}$ ) close to the ones encountered in the field. They show that the concentrations measured with and without the chamber are equivalent. The results of this experiment are reported in Appendix B. Moreover, the temperatures of the Teflon chamber walls and Teflon tube have been measured in direct sunlight and the difference with air temperature is small $\left(<1^{\circ} \mathrm{C}\right)$. We therefore assume that the Teflon wall and tube heating is small and does not affect the $\mathrm{NH}_{3}$ and $\mathrm{NO}$ concentration measurements in the chamber. The results of this experiment are reported in Appendix D. All the details of the calculation are given in Delon et al. (2017) and are briefly summarized here.

$F_{x}=\frac{V}{A_{0}} \frac{\delta C_{x}}{\delta t}$,

where $F_{X}$ is the flux $\left(\mathrm{NO}\right.$ or $\mathrm{NH}_{3}$ ) in nmol m $\mathrm{n} \mathrm{s}^{-1}$, and $\delta C_{X}$ is the concentration variation in the chamber in $\mathrm{nmol} \mathrm{m}^{-3}$ during the temporal interval $\delta t . A_{0}=0.0684 \mathrm{~m}^{2}$ is the surface of the ground covered by the chamber, and $V=$ $0.0123 \mathrm{~m}^{3}$ is the volume of the chamber. This equation is similar to the one in Davidson (1991). The flux is then converted to $\mathrm{ngN} \mathrm{m}^{-2} \mathrm{~s}^{-1}$.

The linear regression is calculated over a 100 to $300 \mathrm{~s}$ time interval after the installation of the chamber on soil for both $\mathrm{NO}$ and $\mathrm{NH}_{3}$. The dilution effect due to mixing of outside air in the chamber was evaluated based on our set-up in which $Q / V=8.13 \times 10^{-4} \mathrm{~s}^{-1}$. It is calculated for each flux separately and is on average $6.7( \pm 1.6) \%$ for NO and $7.7( \pm 1.7) \%$ for $\mathrm{NH}_{3}$. Considering the precision of the analyser $( \pm 0.4 \mathrm{ppbv})$, the detection limit is $0.4 \mathrm{ngN} \mathrm{m}^{-2} \mathrm{~s}^{-1}$ for $\mathrm{NO}$ and $\mathrm{NH}_{3}$ fluxes. According to Appendix $\mathrm{B}$, if the difference in $\mathrm{NH}_{3}$ concentration used to calculate a flux is below $0.9 \mathrm{ppb}$, the resulting flux may not be distinguished from a potential effect of adsorption or desorption onto the chamber walls. The precision of the analysing device (analyser + chamber + tube) may be defined at $0.9 \mathrm{ppb}$ (corresponding to a flux of $0.55 \mathrm{ngN} \mathrm{m}^{-2} \mathrm{~s}^{-1}$ ). In that case, low $\mathrm{NH}_{3}$ fluxes between 0.4 and $0.55 \mathrm{ngN} \mathrm{m}^{-2} \mathrm{~s}^{-1}$ are considered close to zero but are kept in the average daily flux calculation.

The chemical reactions inside the chamber can determine NO consumption and consequently an underestimation of the NO fluxes calculated with our method. This underestimation is taken into account and calculated following the method by Pape et al. (2009) with the relation $k \cdot[\mathrm{NO}] \cdot\left[\mathrm{O}_{3}\right]$. In this relation $k$ is the temperature-dependent reaction rate constant (Pape et al., 2009; Atkinson et al., 2004), [NO] is measured by the Thermo Scientific 17i at soil level just before positioning the chamber for the measurement of soil fluxes, and
$\left[\mathrm{O}_{3}\right]$ at soil level is derived by measurements of $\mathrm{NO}$ and $\mathrm{NO}_{2}$ at soil level made with the Thermo Scientific 17i and measurements of $\mathrm{NO}, \mathrm{NO}_{2}$, and $\mathrm{O}_{3}$ taken on an $8 \mathrm{~m}$ high tower. On the $8 \mathrm{~m}$ high tower, $\mathrm{NO}$ and $\mathrm{NO}_{2}$ were measured with a model $42 \mathrm{C}$ TraceLevel NO- $\mathrm{NO}_{2}-\mathrm{NO}_{x}$ by Thermo Environmental Instruments Inc., calibrated with the same method as the Thermo Scientific 17i and with a $0.05 \mathrm{ppb}$ (2-sigma) detection limit. Ozone was measured on the tower with a model 49i ozone analyser by Thermo Environmental Instruments Inc. with a $1 \mathrm{ppb}$ detection limit. The model 49i ozone analyser was calibrated by comparison with a Thermo Scientific model 49PS reference instrument. The reference instrument is sent twice a year to the French Laboratoire national d'Essais (LNE) for comparison with the National Institute of Standards and Technology (NIST). All data on the tower were sampled at $10 \mathrm{~s} .\left[\mathrm{O}_{3}\right]$ at soil level was then calculated considering the diurnal steady state of the reactions described in Eqs. (2) and (3) using Eq. (4):

$$
\begin{aligned}
& \mathrm{NO}+\mathrm{O}_{3} \rightarrow \mathrm{NO}_{2}+\mathrm{O}_{2}, \\
& \mathrm{NO}_{2} \rightarrow \mathrm{NO}+\mathrm{O}, \\
& {\left[\mathrm{O}_{3}\right]_{\mathrm{sl}}=\frac{[\mathrm{NO}]_{\mathrm{tl}}\left[\mathrm{O}_{3}\right]_{\mathrm{tl}}}{\left[\mathrm{NO}_{2}\right]_{\mathrm{tl}}} \frac{\left[\mathrm{NO}_{2}\right]_{\mathrm{sl}}}{[\mathrm{NO}]_{\mathrm{sl}}},}
\end{aligned}
$$

where []$_{\mathrm{sl}}$ is the concentration at the soil level and [ $]_{\mathrm{tl}}$ is the concentration measured on the tower. In conclusion, we correct NO fluxes for the underestimation of NO fluxes due to chemical reactions inside the chamber with values ranging between $0 \%$ and $63 \%$ ( $8 \%$ on average for the whole campaign).

As studied by Kristensen et al. (2010a, b), $\mathrm{O}_{3}$ deposition can decrease $\mathrm{O}_{3}$ concentration close to soil surface further. However, considering that $\mathrm{O}_{3}$ concentrations calculated near the soil are already very low ( $1 \mathrm{ppb}$ at soil level compared to $24 \mathrm{ppb}$ at $8 \mathrm{~m}$, averaged for the entire measurement campaign), $\mathrm{O}_{3}$ deposition has been considered of secondary importance in this calculation and has not been included. If $\mathrm{O}_{3}$ deposition were to be included it would possibly decrease the correction of NO fluxes and consequently slightly decrease $\mathrm{NO}$ emissions in a negligible proportion compared to the correction already applied for the chemical reactions inside the chamber.

$\mathrm{NH}_{3}$ measurements have not been corrected from a possible interaction with particulate matter (PM) as PM concentrations (not measured at Savé) are assumed to be low because Savé is located in a rural area far from anthropogenic pollution influence. The walls of the Teflon chamber are cleaned daily to reduce any interference of $\mathrm{NH}_{3}$ with $\mathrm{PM}$ deposition in the chamber. The effect of PM, even at low PM concentrations, may reduce the measurement accuracy and induce an uncertainty on the detection of the $\mathrm{NH}_{3}$ flux from soil. This uncertainty has not been assessed quantitatively, but the reader must keep in mind that $\mathrm{NH}_{3}$ fluxes may be estimated with less accuracy because of the presence of PM, especially for low fluxes. 


\subsection{Data quality check}

A quality check method based on the following criteria is used to select observed fluxes (Delon et al., 2017).

- The coefficient of determination for linear regression $R^{2}$ has to be higher than 0.4 (considered a significant correlation) for $\mathrm{NH}_{3}$ fluxes and higher than 0.8 for $\mathrm{NO}$ fluxes. The variation of $\mathrm{NH}_{3}$ is less stable than for $\mathrm{NO}$ because of potential interaction with PM in the chamber. However, $80 \%$ of the $R^{2}$ values were superior to 0.6 for $\mathrm{NH}_{3}$, and $100 \%$ for NO. Examples of the variation in time of the concentration of $\mathrm{NH}_{3}$ and $\mathrm{NO}$ in the chamber are shown in Appendix $\mathrm{E}$ for two different soils.

- A flux error was estimated by calculating the dispersion of points around the linear regression's slope. According to this method, the dispersion for NO flux calculation is between $5 \%$ and $12 \%$, and the dispersion for $\mathrm{NH}_{3}$ flux calculation is between $15 \%$ and $20 \%$.

- The concentration difference between the last and the first $\mathrm{NH}_{3}$ measurement point has to be more than $0.4 \mathrm{ppb}$ (sensitivity of the analyser). $R^{2}$ was generally lower than 0.4 for concentration differences below $0.4 \mathrm{ppb}$.

Finally, $351 / 488(72 \%) \quad \mathrm{NH}_{3}$ flux measurements and 459 / 488 (94\%) NO flux measurements are considered valid. Among the $351 \mathrm{NH}_{3}$ valid fluxes, $30 \%$ are derived from a concentration difference of less than $0.9 \mathrm{ppb}$.

\section{Uncertainty of the $\mathrm{NH}_{3}$ flux calculation}

Despite all precautions to reduce adsorption on the chamber walls and/or interaction with PM in air (see Appendix B, $\mathrm{C}, \mathrm{D}$, and $\mathrm{E}$ ), $R^{2}$ is less good for $\mathrm{NH}_{3}$ due to potential chemical or physical interactions of the material with $\mathrm{NH}_{3}$ (whereas this is considered negligible in this study). However, no absolute correction for adsorption can be calculated under field conditions. Teflon remains the more reliable material to measure $\mathrm{NH}_{3}$, as shown in Sauren et al. (1989), who find that Teflon has the lowest adsorption affinity for $\mathrm{NH}_{3}$ (compared with aluminium, paraffin, and gold), but a passivation time lag remains for $\mathrm{NH}_{3}$ detection in measurements systems (Yokelson et al., 2003).

\subsection{Meteorological station}

Continuous in situ observations of meteorological variables, including air and soil temperature and moisture, rainfall, wind speed, wind direction, radiation, and energy balance components, were taken at the Savè site as part of the DACCIWA campaign. Data are provided as $1 \mathrm{~min}$ averages, apart from energy fluxes, which are given as 30 min averages (Derrien et al., 2016; Kohler et al., 2016; Handwerker et al.,
2016; Wieser et al., 2016). An overview of the complete set of instrumentation and measurements is given by Brooks et al. (2019), while a summary of the available groundbased meteorological observations is given by Kalthoff et al. (2018). In this study we present soil moisture measured in two distinct locations of the Savè site by Karlsruhe Institute of Technology (KIT) instrumentation at $5 \mathrm{~cm}$ of depth on grassland and average soil moisture, between 0 and $30 \mathrm{~cm}$, measured by Université Paul Sabatier (UPS) instrumentation in the maize field. Details on the instrumentation are given by Brooks et al. (2019). We include soil moisture measured with both systems, as the inter-comparison of the two methods is out of the scope of this study.

\subsection{Soil characteristics (texture, $\mathrm{pH}, \mathrm{N}$ content)}

Soil samples were collected with a cylinder of known volume $\left(290 \mathrm{~cm}^{3}\right)$ during the measurement campaign to analyse the biogeochemical characteristics of the site. Soil samples $(0-5 \mathrm{~cm})$ were taken for each land cover type for which NO and $\mathrm{NH}_{3}$ fluxes were measured. A total of 15 samples were collected at the four different land cover types three to four times during the campaign.

Samples were dried in ambient conditions (mean daytime temperature is approximately $26^{\circ} \mathrm{C}$; Kalthoff et al., 2017) and stored in the dark. After drying, the weight of the samples was measured to determine the bulk density $\left(d_{\mathrm{a}}=\right.$ dry soil mass / total volume), which was found to be $1.24 \pm 0.14 \mathrm{~g} \mathrm{~cm}^{-3}$ Assuming a density of soil particles $\left(d_{\mathrm{r}}\right)$ of $2.6 \mathrm{~g} \mathrm{~cm}^{-3}$, the water-filled pore space (WFPS) is calculated with Eq. (5):

$\mathrm{WFPS}=\mathrm{SM} /\left(1-d_{\mathrm{a}} / d_{\mathrm{r}}\right)$,

where SM is soil moisture in percent.

Soil samples were analysed for the determination of texture, ammonium concentrations $\left[\mathrm{NH}_{4}^{+}\right], \mathrm{C} / \mathrm{N}$ ratio, total $\mathrm{C}$, total $\mathrm{N}$, and $\mathrm{pH}$ at the GALYS laboratory (http:// www.galys-laboratoire.fr, last access: 15 February 2019, NF EN ISO/CEI 17025: 2005). The analyses were performed 2 months after sampling. We assume that the ammonium content in litter or soils is not modified by volatilization or chemical transformation during transport and storage because of the very low soil moisture level in samples. Indeed, when collected, WFPS of the samples ranged between $6 \%$ and $14 \%$ (mean $8.5 \pm 3.5 \%$ ) and soil temperature between 35 and $38^{\circ} \mathrm{C}$ (data obtained from the databases described in Brooks et al., 2019). Bai et al. (2013, and references therein) have found that significant changes in nitrification and net mineralization (influencing the ammonium content) may occur when soil temperature rises to $35^{\circ} \mathrm{C}$ (the optimum for nitrification) for optimal soil moisture conditions (WFPS $=20 \%$; Oswald et al., 2013). In the present study, soil temperatures when sampling were equal to or above the optimum, and WFPS was below the optimum, reducing the nitrification efficiency and the change in ammonium con- 
tent. Several authors have published results for ammonium concentrations measured in soils dried in ambient air. For example, Dick et al. (2006) collected topsoil after the wet season at two sites in Senegal. The authors state that their soils were considered dry when collected and were air-dried in the midday sun immediately after collection. The protocol used in our study is identical. Other studies (Bai et al., 2010; Cassity-Duffrey et al., 2014; Vanlauwe et al., 2002) also published ammonium measurements made on air-dried soils from seasonally dry climates with comparable textures to the soil in Savé. Soil texture is determined following norm NF X 31e107. Clay ( $<2 \mu \mathrm{m})$, fine silt (2 to $20 \mu \mathrm{m})$, coarse silt $(20$ to $50 \mu \mathrm{m})$, and total sand (50 to $2000 \mu \mathrm{m})$ are determined without decarbonation. Organic carbon and total carbon are determined following norm NF ISO 10694. All carbon in the sample is transformed into $\mathrm{CO}_{2}$. Then $\mathrm{CO}_{2}$ is measured by thermal conductibility. NF ISO 13878 is used for total N. Mineral nitrogen is determined following an internal method MT-AZM adapted from norm NF ISO 14256-2. This method uses a potassium chloride solution and is COFRAC certified. The sample is heated at $1000{ }^{\circ} \mathrm{C}$ with $\mathrm{O}_{2}$. Products of combustion or decomposition are reduced in $\mathrm{N}_{2} \cdot \mathrm{N}_{2}$ is then measured by thermal conductibility (catharometer); $\mathrm{pH}$ is determined according to norm NF ISO 10390, with soil samples stirred with water (ratio $1 / 5$ ).

\subsection{Soil ammonia emission potential $\Gamma_{\mathrm{g}}$ and compensation point $\chi_{\mathrm{g}}$}

Measurements of soil $\mathrm{pH}$ and ammonium concentrations $\left[\mathrm{NH}_{4}^{+}\right]$are used to quantify the soil emission potentials for the different land cover types at the measurement site. The soil emission potential $\Gamma_{\mathrm{g}}$ is the ratio of $\left[\mathrm{NH}_{4}^{+}\right]$to $\left[\mathrm{H}^{+}\right]$concentrations in the water solution of the soil $\left(\mathrm{mol} \mathrm{L}^{-1}\right)$. A large $\Gamma_{\mathrm{g}}$ indicates that the soil has a high propensity to emit $\mathrm{NH}_{3}$, considering that the potential emission of $\mathrm{NH}_{3}$ depends on the availability of ammonium in the soil and on $\mathrm{pH}$.

The soil compensation point $\left(\chi_{\mathrm{g}}\right)$ has been calculated from the emission potential $\Gamma_{\mathrm{g}}$ as a function of soil surface temperature ( $T_{\mathrm{g}}$ in $\left.\mathrm{K}\right)$ according to Wentworth et al. (2014):

$\chi_{\mathrm{g}}(\mathrm{ppb})=13587 \cdot \Gamma_{\mathrm{g}} \cdot e^{-\left(10396 \mathrm{KTg}^{-1}\right)} \times 10^{9}$.

The soil compensation point indicates the equilibrium between gaseous $\mathrm{NH}_{3}$ in the soil pore space and $\left[\mathrm{NH}_{4}^{+}\right]$in the soil solution, i.e. the concentration of $\mathrm{NH}_{3}$ for which the $\mathrm{NH}_{3}$ flux switches from emission to deposition (or vice versa).

\subsection{Stepwise multiple regression analysis}

A stepwise linear multiple regression analysis was performed between daytime averaged gas fluxes of $\mathrm{NO}$ and $\mathrm{NH}_{3}$ and relevant available daily averaged variables such as wind speed, soil temperature at $5 \mathrm{~cm}$, soil moisture at $5 \mathrm{~cm}$, soil heat flux, outgoing longwave radiation, and incoming shortwave radiation. Soil parameters such as mineral nitrogen, total $\mathrm{N}$ and or- ganic $\mathrm{C}$, soil texture, and $\mathrm{pH}$ could not be used for this regression analysis since their relative measurements did not have the same temporal resolution as the other parameters. The $\mathrm{R}$ software (http://www.R-project.org, last access: 15 February 2019) was used to provide the results of this linear regression analysis.

\subsection{GEOS-Chem}

GEOS-Chem is a global three-dimensional model of tropospheric chemistry driven by meteorological input from the NASA Goddard Earth Observing System (http://acmg.seas. harvard.edu/geos/; last access: 15 February 2019, Bey et al., 2001). In this study we use GEOS-Chem version 10-01, which includes the process-based parameterization of soil NO emission by Hudman et al. (2012). This parameterization represents available nitrogen $(\mathrm{N})$ in soils using biomespecific emission factors, online wet and dry deposition of $\mathrm{N}$, and fertilizer and manure $\mathrm{N}$ derived from a spatially explicit dataset, distributed using seasonality derived from data obtained by the Moderate Resolution Imaging Spectrometer (MODIS). Emissions are a smooth function of soil moisture and temperature consistent with point measurements and ecosystem-scale experiments. This parameterization also included pulsing following soil wetting by rain or irrigation, represented as a function dependent on dry spell length. The parameterization by Hudman et al. (2012) was successfully evaluated for pulsing events in the central Sahel $\left(0-30^{\circ} \mathrm{W}\right.$, $\left.12-18^{\circ} \mathrm{N}\right)$.

Boundary conditions for our experiment are generated from a global GEOS-Chem simulation at $4^{\circ} \times 5^{\circ}$ horizontal resolution. The regional GEOS-Chem model for West Africa runs at a horizontal resolution of $0.25^{\circ} \times 0.3125^{\circ}$ (latitudes $6^{\circ} \mathrm{S}-16^{\circ} \mathrm{N}$, longitudes $\left.18.125^{\circ} \mathrm{W}-26.875^{\circ} \mathrm{E}\right)$ and a vertical resolution of 47 levels (up to $0.01 \mathrm{hPa}$ ). Meteorology is driven by the NASA GMAO (Global Modeling and Assimilation Office) GEOS-FP (Forward Processing) assimilated meteorological data. The global model is spun up from 1 May 2015 to 1 May 2016. The global simulation is then run from 1 May 2016 to 1 August 2016, outputting boundary condition files for West Africa. The regional West Africa simulation is then run from 1 May 2016 to 1 August 2016 using the $4^{\circ} \times 5^{\circ}$ boundary conditions from the global simulation. All simulations use the GEOS-FP meteorology which has a $3 \mathrm{~h}$ time resolution. We used the same MODIS-Köppen land cover map as in Hudman et al. (2012; available at http:/glcf.umd.edu/data/lc, last access: 15 February 2019), which includes 24 land cover types. In this simulation we use EDGAR v4.2 (EC-JRC/PBL, 2011) for anthropogenic emissions, GFED4 (Giglio et al., 2013) for biomass burning emissions, and MEGAN v2.1 (Guenther et al., 2012) for biogenic emissions of volatile organic compounds. The same emission inventories are used for both the boundary conditions and the West Africa simulation. 


\section{Results and discussion}

\subsection{Meteorological data}

Mean air temperature averaged over the whole campaign was $25.4 \pm 2.6^{\circ} \mathrm{C}$, mean wind speed was $1.3 \pm 0.6 \mathrm{~m} \mathrm{~s}^{-1}$, mean relative air humidity is $86.3 \pm 10.5 \%$, mean soil temperature was $25.2 \pm 3.4^{\circ} \mathrm{C}$, mean KIT soil moisture at $5 \mathrm{~cm}$ was $7.1 \pm 3.6 \%$, and mean UPS soil moisture averaged between 0 and $30 \mathrm{~cm}$ was $4.5 \pm 2.8 \%$. Total KIT precipitation was $198 \mathrm{~mm}$ for the whole campaign, and total UPS precipitation was $215 \mathrm{~mm}$.

Median diurnal cycles of air temperature, specific humidity, and precipitation are reported in Kalthoff et al. (2018). Knippertz et al. (2017) distinguish four different phases of the monsoon season during the DACCIWA campaign (14 June to 30 July 2016) over the DACCIWA focus region $\left(5-10^{\circ} \mathrm{N}, 8^{\circ} \mathrm{W}-8^{\circ} \mathrm{E}\right)$, which covers a wide area of West Africa (see Fig. 1, Knippertz et al., 2017). The division into phases is mainly based on the north-south precipitation difference between the coastal zone $\left(0-7.5^{\circ} \mathrm{N}\right)$ and the Sudanian-Sahelian zone $\left(7.5-15^{\circ} \mathrm{N}\right)$, both averaged across the longitude range $8^{\circ} \mathrm{W}-8^{\circ} \mathrm{E}$. Savè $\left(8.03^{\circ} \mathrm{N}\right)$ is located very close to the border between the two zones, with a rainfall pattern that seems to follow more closely that of the coastal zone rather than that of the northern inland Sudanian-Sahelian zone. These four phases are the pre-onset phase characterized by a rainfall maximum near the coast (before 21 June, phase 1), the post-onset phase during which the rainfall maximum occurred inland (22 June-20 July, phase 2), the wet westerly regime when the rainfall maximum shifted back to the coast (21-26 July, phase 3), and the recovery of the monsoon with a shift of the rainfall maximum inland (27 July until the end of the campaign, phase 4). A specific period within phase 2 is indicated as a "vortex", during which an unusual development occurred (9-16 July): in the north, a cyclonic feature slowly propagated from eastern Mali to Cape Verde and in the south, and an anticyclonic vortex tracked in the west-northwesterly direction along the Guinean coast (see Knippertz et al., 2017, for a more detailed description). At the Savè site the most intense rainfall events happened the day before the first soil fluxes observation, on 15 June 2016, and towards the end of the measurement campaign between 20 and 23 July 2016. Other minor rainfall events are recorded on 19 and 27 June and 8, 12, 13, 24, and 26 July. Daily rainfall measurements are reported in Figs. 2 to 5.

\subsection{Soil texture, soil organic carbon, total nitrogen, $\mathrm{pH}$, and ammonium content}

Bare soil recorded a lower amount of total sand $(83.75 \pm$ $1.82 \%)$ and a higher amount of clay $(5.13 \pm 0.63 \%)$, fine silt $(5.13 \pm 0.96 \%)$, and coarse silt $(5.98 \pm 0.51 \%)$. Grassland recorded a higher amount of total sand $(89.20 \pm 0.71 \%)$ and a lower amount of clay $(3.15 \pm 0.50 \%)$ and fine silt
$(2.93 \pm 0.32 \%)$, while intermediate values were found for the maize field and forest (Table 3 ). These values determine the classification of sandy soil for all measurement sites.

Soil organic carbon $(\mathrm{C})$ and total nitrogen $(\mathrm{N})$ are $12.2 \pm$ 5.7 and $0.95 \pm 0.51 \mathrm{~g} \mathrm{~kg}^{-1}$, respectively, averaged for all land cover types over the entire campaign. Table 4 gives soil characteristics for each land cover type, including individual values for the $\mathrm{C} / \mathrm{N}$ ratio, soil organic $\mathrm{C}$, and total $\mathrm{N}$ for the entire field campaign. The highest average soil organic $\mathrm{C}$ was measured for bare soil $\left(17.3 \pm 5.9 \mathrm{~g} \mathrm{~kg}^{-1}\right)$ and the lowest soil organic $\mathrm{C}$ was measured for grassland $\left(6.2 \pm 1.3 \mathrm{~g} \mathrm{~kg}^{-1}\right)$, while the maize field and forest site accounted for $14.1 \pm 2.9$ and $11.4 \pm 4.5 \mathrm{~g} \mathrm{~kg}^{-1}$ of soil organic $\mathrm{C}$, respectively. The highest average total $\mathrm{N}$ was measured for bare soil $\left(1.44 \pm 0.51 \mathrm{~g} \mathrm{~kg}^{-1}\right)$ and the lowest total $\mathrm{N}$ was measured for grassland $\left(0.44 \pm 0.04 \mathrm{~g} \mathrm{~kg}^{-1}\right)$, while the maize field and forest site accounted for similar amounts of total $\mathrm{N}$ : $0.99 \pm 0.19$ and $0.94 \pm 0.48 \mathrm{~g} \mathrm{~kg}^{-1}$, respectively. Values of $\mathrm{C} / \mathrm{N}$, soil organic $\mathrm{C}$, and total $\mathrm{N}$ recorded for grassland at the Savè site compare closely to those reported by Delon et al. (2017, Table 2) for the semi-arid site of Dahra $\left(15^{\circ} 24^{\prime} \mathrm{N}\right.$ $15^{\circ} 25^{\prime} \mathrm{W}$ ), Senegal. Our values of $\mathrm{C} / \mathrm{N}$ and total $\mathrm{N}$ for grassland are also close to those reported by Le Roux et al. (1995, Table 1) and Lata et al. (2004) for the wet savanna ecosystem of Lamto $\left(6^{\circ} 13^{\prime} \mathrm{N}, 5^{\circ} 20^{\prime} \mathrm{W}\right)$, Ivory Coast, although we observe lower values of soil organic $\mathrm{C}$ compared to these studies. Values of $\mathrm{C} / \mathrm{N}$ and soil organic $\mathrm{C}$ recorded for the maize field at the Savè site are slightly higher than those recorded by Barthès et al. (2004) in a maize field at Agonkanmey $\left(6^{\circ} 24^{\prime} \mathrm{N}, 2^{\circ} 20^{\prime} \mathrm{E}\right)$, near Cotonou in southern Benin.

All the sites listed in the comparison in the previous paragraph are sandy, as is the Savè site. The Dahra site (Delon et al., 2017) also shows similar pH as our site (Table 5), while lower $\mathrm{pH}$ (acidic or near neutral) was recorded at the sites of Lamto (Le Roux et al., 1995; Lata et al., 2004) and Agonkanmey (Barthès et al., 2004). Table 5 provides individual values of $\mathrm{pH},\left[\mathrm{NH}_{4}^{+}\right], \Gamma_{\mathrm{g}}$, and $\chi_{\mathrm{g}}$ for the entire field campaign. The highest average $\mathrm{pH}$ was observed for bare soil (8.23) and the lowest for the forest site (7.07), while measured average $\mathrm{pH}$ was 7.27 for grassland and 7.70 for the maize field. The $\left[\mathrm{NH}_{4}^{+}\right]$content averaged for all land cover types over the entire campaign is $5.33 \pm 4 \mathrm{mg} \mathrm{kg}^{-1}$. The highest average $\left[\mathrm{NH}_{4}^{+}\right]$was recorded for the maize field $\left(7.9 \pm 6 \mathrm{mg} \mathrm{kg}^{-1}\right)$ and the lowest for grassland $\left(2.0 \pm 0.3 \mathrm{mg} \mathrm{kg}^{-1}\right)$. Average $\left[\mathrm{NH}_{4}^{+}\right]$is $6.2 \pm 5$ and $7.0 \pm 2.2 \mathrm{mg} \mathrm{kg}^{-1}$ for forest and bare soil, respectively. Dick et al. (2006) have found $\mathrm{NH}_{4}^{+}$concentrations between 2 and $8 \mathrm{mgN} \mathrm{kg}^{-1}$ in Senegalese soils, which is very close to our results. Vanlauwe et al. (2002) have found values between 0.8 and $1.4 \mathrm{mgN} \mathrm{kg}^{-1}$ in West African moist savanna soils (in Togo and Nigeria).

The higher soil organic $\mathrm{C}$ and $\mathrm{N}$ over bare soil could be due to the fact that these bare soil patches experienced recent burning (Santín and Doerr, 2016). The higher $\left[\mathrm{NH}_{4}^{+}\right]$over the maize field could be caused by chicken excreta, as chickens 




Figure 2. (a) Daily total precipitation ( $\mathrm{mm}$ ), daily mean soil moisture at $5 \mathrm{~cm}(\%)$ measured by the Karlsruhe Institute of Technology (KIT), daily mean soil moisture averaged between 0 and $30 \mathrm{~cm}$ measured by Université Paul Sabatier (UPS) instrumentation, and daytime mean NO fluxes in $\mathrm{ngN} \mathrm{m}^{-2} \mathrm{~s}^{-1}$ measured at the "bare soil site"; (b) daytime mean $\mathrm{NH}_{3}$ fluxes in $\mathrm{ngN} \mathrm{m}^{-2} \mathrm{~s}^{-1}$; (c) daytime mean $\mathrm{NO}$ and $\mathrm{NH}_{3}$ concentrations in $\mathrm{ppb}$. Vertical bars show the standard deviation from individual fluxes and concentrations.

were roaming over the maize field (Paillat et al., 2005; Tiquia and Tam, 2000).

\subsection{Soil emission potential $\Gamma_{\mathrm{g}}$ and compensation point $\chi_{\mathrm{g}}$}

The mean soil emission potential for the Savè site is $43714 \pm 58077$, with values ranging from 380 to 159343 . The highest values of soil emission potential are observed for bare soil (113672 \pm 67788$)$, followed by maize field (33880 \pm 20680$)$, forest $(11982 \pm 11061)$, and grassland $(4929 \pm 4409)$. The ammonia compensation point ranges between 5 and $2215 \mathrm{ppb}$, with soil temperatures between 25 and $29^{\circ} \mathrm{C}$. The highest values of $\chi_{\mathrm{g}}$ are observed for bare soil (1607 \pm 993$)$, followed by maize field ( $473 \pm 317)$, forest (175 \pm 167$)$, and grassland (58 \pm 47$)$. Our values of soil emission potential for bare soil and maize (no fertilization) are comparable to those presented in Massad et al. (2010, Table 4), although those data come from measurements taken in different ecosystems. Both $\Gamma_{\mathrm{g}}$ and $\chi_{\mathrm{g}}$ values recorded at the Savè site exceed those recorded by Delon et al. (2017) over a grazed semi-arid Sahelian ecosystem in Senegal.

\subsection{NO fluxes}

NO fluxes from soil measured during the field campaign range between 0 and $48.05 \mathrm{ngN} \mathrm{m}^{-2} \mathrm{~s}^{-1}$. NO fluxes averaged over all land cover types are $4.79 \pm 5.59 \mathrm{ngN} \mathrm{m}^{-2} \mathrm{~s}^{-1}$, while average NO fluxes for each land cover type are $8.05 \pm$ $3.49 \mathrm{ngN} \mathrm{m}^{-2} \mathrm{~s}^{-1}$ for bare soil, $3.73 \pm 1.76 \mathrm{ngN} \mathrm{m}^{-2} \mathrm{~s}^{-1}$ for the maize field, $2.87 \pm 1.49 \mathrm{ngN} \mathrm{m}^{-2} \mathrm{~s}^{-1}$ for forest, and $2.82 \pm 3.46 \mathrm{ngN} \mathrm{m}^{-2} \mathrm{~s}^{-1}$ for grassland. Soil emissions of $\mathrm{NO}$ from the different land cover types provide similar values, and NO emissions from bare soil are higher on average, but have a larger standard deviation (Table 6).

Other measurements of biogenic NO soil emissions from the West African wet savanna can be found in Delon et al. (2012, Table 7). We find that our measured NO soil emis- 


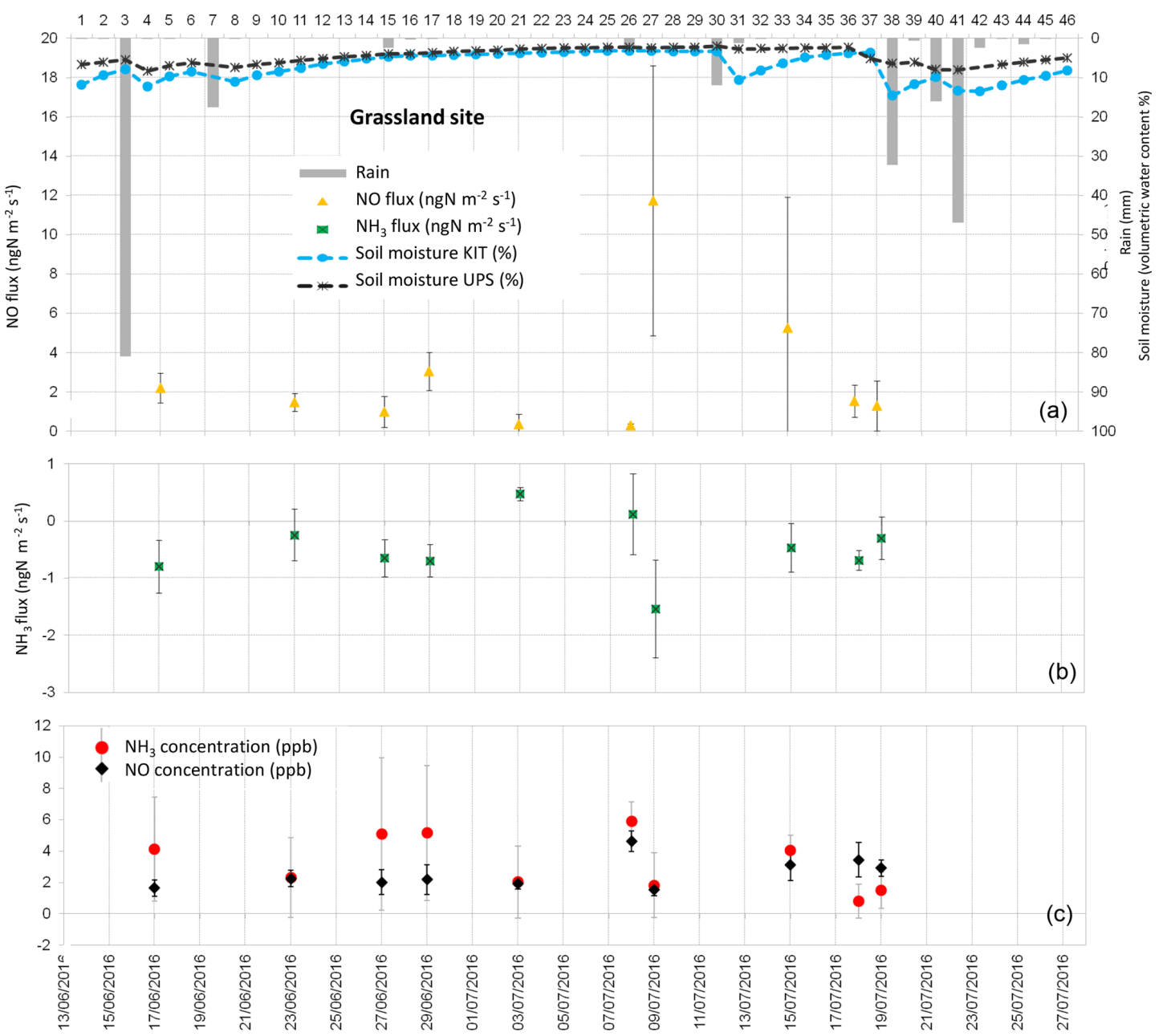

Figure 3. (a) Daily total precipitation (mm), daily mean soil moisture at $5 \mathrm{~cm}(\%)$ measured by the Karlsruhe Institute of Technology (KIT), daily mean soil moisture averaged between 0 and $30 \mathrm{~cm}$ measured by Université Paul Sabatier (UPS) instrumentation, and daytime mean $\mathrm{NO}$ fluxes in $\mathrm{nN} \mathrm{m}^{-2} \mathrm{~s}^{-1}$ measured at the grassland site. (b) Daytime mean $\mathrm{NH}_{3}$ fluxes in $\mathrm{ngN} \mathrm{m}^{-2} \mathrm{~s}^{-1}$. (c) Daytime mean $\mathrm{NO}$ and $\mathrm{NH}_{3}$ concentrations in $\mathrm{ppb}$. Vertical bars show the standard deviation from individual fluxes and concentrations.

sions averaged over all land cover types are higher than those measured from other wet savanna sites. Our measurements are in better agreement with emissions from dry savanna grasslands (Delon et al., 2012) and with measurements from a semi-arid savanna, with over $80 \%$ sandy soil, in South Africa (Parsons et al., 1996; Scholes et al., 1997). However, these studies measured NO emissions during different seasons and soil moisture conditions compared to our study. For example, Parsons et al. (1996) recorded NO emissions up to $20 \mathrm{ngN} \mathrm{m}^{-2} \mathrm{~s}^{-1}$ over an open savanna during the period from the end of the dry season to the beginning of the wet season. Nitric oxide emissions of the same magnitude as in our study were also recorded over a grazed semi-arid Sahelian ecosystem in Senegal during the month of July by Delon et al. (2017): $5.7 \pm 3.1 \mathrm{ngN} \mathrm{m}^{-2} \mathrm{~s}^{-1}$ in July 2012 and $5.1 \pm 2.1 \mathrm{ngN} \mathrm{m}^{-2} \mathrm{~s}^{-1}$ in July 2013 .
Daytime means of NO concentrations are measured close to the soil $(0.1 \mathrm{~m}$, half-height of the chamber) and reported in Figs. 2 to 5. Daytime means of NO concentration vary from 1.28 to $5.40 \mathrm{ppb}$ for all sites. The average concentration during the whole campaign at all sites is $2.70 \pm 1.03 \mathrm{ppb}$. The average NO concentration is $2.97 \pm 1.49 \mathrm{ppb}$ on bare soil, $2.57 \pm 0.96 \mathrm{ppb}$ on grassland, $2.55 \pm 0.83$ on maize, and $2.76 \pm 0.65 \mathrm{ppb}$ on forest soil (Table 6). The concentrations are quasi-equivalent for all sites. As these concentrations are low, they do not lead to NO deposition on soil and the NO flux stays positive. In fact, NO deposition has been measured in other studies only in the case of high NO concentrations (> 60 ppb; Laville et al., 2011).

Figures 2 to 5 show daytime averaged $\mathrm{NO}$ and $\mathrm{NH}_{3}$ fluxes ( \pm 1 standard deviation) for each land cover type, along with precipitation and soil moisture. The spatial variability of $\mathrm{NO}$ fluxes is high, especially for bare soil, forest, and the maize 

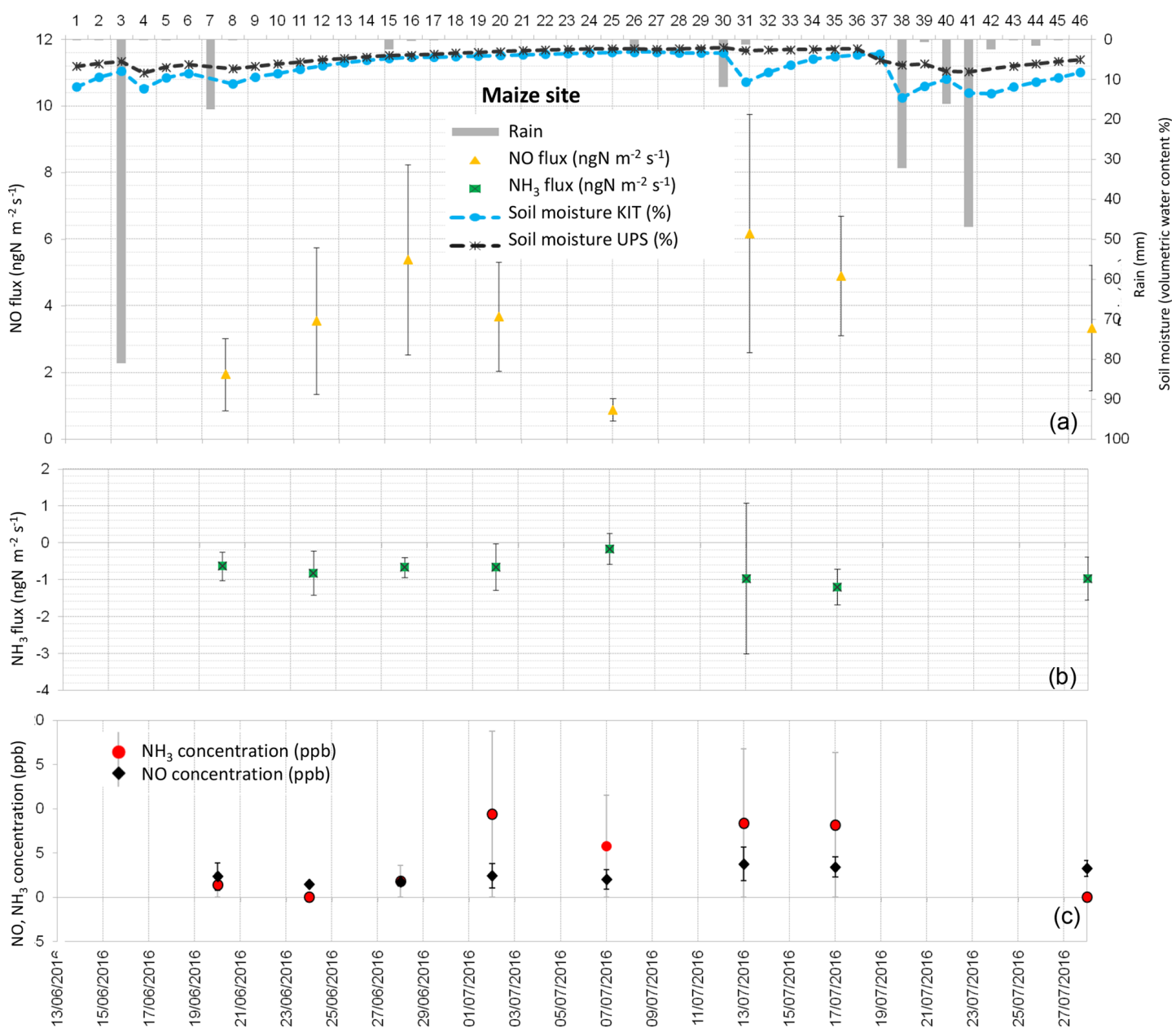

Figure 4. (a) Daily total precipitation ( $\mathrm{mm})$, daily mean soil moisture at $5 \mathrm{~cm}(\%)$ measured by the Karlsruhe Institute of Technology (KIT), daily mean soil moisture averaged between 0 and $30 \mathrm{~cm}$ measured by Université Paul Sabatier (UPS) instrumentation, and daytime mean NO fluxes in $\mathrm{ngN} \mathrm{m}^{-2} \mathrm{~s}^{-1}$ measured at the maize field site. (b) Daytime mean $\mathrm{NH}_{3}$ fluxes in $\mathrm{ngN} \mathrm{m}^{-2} \mathrm{~s}^{-1}$. (c) Daytime mean $\mathrm{NO}_{\text {and }} \mathrm{NH}_{3}$ concentrations in $\mathrm{ppb}$. Vertical bars show the standard deviation from individual fluxes and concentrations.

field where underground roots, not visible at the surface, are heterogeneously distributed. These roots are likely to influence the ammonium content of the soil and the subsequent NO flux measurement. The standard deviation is generally smaller for grassland (except for two days, 9-13 July), where the vegetation (and the root distribution) is more homogeneous. The variation of soil moisture is consistent with the presence of rain events, showing a sharper increase in soil moisture at $5 \mathrm{~cm}$, especially after rainfall following dry periods.

NO emissions from bare soil and grassland show an increase, sharper for grassland, 1 to 2 days after the rain event on 8 July. The longer rain event between 20 and 24 July does not seem to produce an increase in NO emissions (data available only for maize field and forest). This might be linked with the non-linear relationship between NO biogenic soil emissions and soil water content (Oswald et al., 2013). In fact, a light precipitation event $(5-15 \mathrm{~mm})$ occurring on dry soils can result in a large flux of NO (Meixner and Yang, 2006; Hartley and Schlesinger, 2000). However, when soil moisture stays at an equivalent level, after several rain events, pulse emissions do not occur (Millet et al., 2005). Due to this non-linear character of NO fluxes, no direct correlation was found between NO fluxes and environmental variables such as soil moisture or soil temperature taken individually. Moreover, soil temperature and soil moisture were not measured on the same soil parcel in which the soil fluxes were measured and the location of the soil flux measurements was not kept constant even for the same land cover type on the same measurement day. This measurement protocol was designed to give an estimate of soil fluxes at a large ecosystem scale, rather than reproducing the relationships between soil fluxes and meteorological variables, like soil temperature and soil moisture.

A multiple linear regression analysis was performed between daytime mean NO fluxes and the following vari- 




Figure 5. (a) Daily total precipitation ( $\mathrm{mm}$ ), daily mean soil moisture at $5 \mathrm{~cm}(\%)$ measured by the Karlsruhe Institute of Technology (KIT), daily mean soil moisture averaged between 0 and $30 \mathrm{~cm}$ measured by Université Paul Sabatier (UPS) instrumentation, and daytime mean NO fluxes in $n g N m^{-2} \mathrm{~s}^{-1}$ measured at the forest site. (b) Daytime mean $\mathrm{NH}_{3}$ fluxes in $\mathrm{ngN} \mathrm{m}^{-2} \mathrm{~s}^{-1}$. (c) Daytime mean $\mathrm{NO}$ and $\mathrm{NH}_{3}$ concentrations in ppb. Vertical bars show the standard deviation from individual fluxes and concentrations.

ables: wind speed, soil temperature at $5 \mathrm{~cm}$, soil moisture at $5 \mathrm{~cm}$, soil heat flux, upward longwave radiation, and downward shortwave radiation. This regression gives $R^{2}=0.49$ ( $p$ value $=0.004)$, indicating a weak but existing relationship between those variables and NO soil emissions, while the regression was weak between NO fluxes and each individual variable. This correlation shows the influence of these environmental variables considered collectively on NO fluxes, highlighting the underlying mechanisms responsible for NO release to the atmosphere. Our experiment does not show the details of microbial and physical processes driving soil fluxes at a single point because measurements are done at different locations every day, but aims to estimate the spatial variability of fluxes at the ecosystem scale.

The NO flux estimated in this study does not consider the impact of vegetation on the net ecosystem flux, as we focus on soil fluxes only. However, the net emission to the atmosphere should take into account the oxidation of $\mathrm{NO}$ to $\mathrm{NO}_{2}$ and the eventual redeposition of $\mathrm{NO}_{2}$ on the vegetation, i.e. what is called the canopy reduction factor and is assumed to be a linear function of the leaf area index (e.g. Yienger and Levy, 1995; Ganzeveld et al., 2002).

\section{5 $\mathrm{NH}_{3}$ fluxes}

$\mathrm{NH}_{3}$ fluxes measured during the field campaign range between -6.59 and $4.96 \mathrm{ngN} \mathrm{m}^{-2} \mathrm{~s}^{-1}$. Ammonia fluxes averaged over all land cover types are $-0.91 \pm 1.27 \mathrm{ngN} \mathrm{m}^{-2} \mathrm{~s}^{-1}$, showing a predominance of $\mathrm{NH}_{3}$ deposition over emission, which is verified for every land cover type, with an average value of $-1.33 \pm 0.86 \mathrm{ngN} \mathrm{m}^{-2} \mathrm{~s}^{-1}$ for bare soil, $-0.75 \pm 0.31 \mathrm{ngN} \mathrm{m}^{-2} \mathrm{~s}^{-1}$ for the maize field, $-0.48 \pm 0.55 \mathrm{ngN} \mathrm{m}^{-2} \mathrm{~s}^{-1}$ for grassland, and $-0.30 \pm$ $0.38 \mathrm{ngN} \mathrm{m}^{-2} \mathrm{~s}^{-1}$ for forest (Table 6). Low positive ammonia fluxes, indicating average $\mathrm{NH}_{3}$ emission, are only recorded during 3 days, between 6 and 8 July, after the 
Table 2. List of plant species at the Savè site. The list of common names is not considered to be exhaustive.

\begin{tabular}{|c|c|c|c|c|}
\hline Soil type & & Plant family & Plant species & Common name $\mathrm{s}^{-1}$ \\
\hline \multirow[b]{2}{*}{$\begin{array}{l}\text { Next to grass- } \\
\text { land and forest }\end{array}$} & Dominant tree species & $\begin{array}{l}\text { Anacardiaceae } \\
\text { Fabaceae }\end{array}$ & $\begin{array}{l}\text { Anacardium occidentale } \\
\text { Daniellia oliveri } \\
\text { Pterocarpus erinaceus }\end{array}$ & $\begin{array}{l}\text { cashew tree } \\
\text { African copaiba balsam tree } \\
\text { barwood, muninga, vène, mukwa }\end{array}$ \\
\hline & Dominant ground species & $\begin{array}{l}\text { Cleomaceae } \\
\text { Fabaceae } \\
\text { Poaceae }\end{array}$ & $\begin{array}{l}\text { Cleome sp. } \\
\text { Crotalaria } \mathrm{sp} . \\
\text { Mucuna } \mathrm{sp} . \\
\text { Imperata cylindrica } \\
\text { Rhynchelytrum repens }\end{array}$ & $\begin{array}{l}\text { spider flowers, spider plants } \\
\text { rattlepod or rattlebox } \\
\text { velvet bean } \\
\text { cogon grass, cotton wool grass, kura-kura } \\
\text { rose natal grass }\end{array}$ \\
\hline \multirow{3}{*}{$\begin{array}{l}\text { Next to } \\
\text { maize field }\end{array}$} & Dominant tree species & $\begin{array}{l}\text { Anacardiaceae } \\
\text { Arecaceae } \\
\text { Caricaceae } \\
\text { Lamiaceae } \\
\text { Meliaceae }\end{array}$ & $\begin{array}{l}\text { Mangifera indica } \\
\text { Cocos nucifera } \\
\text { Carica papaya } \mathrm{L} . \\
\text { Tectona grandis } \\
\text { Azadirachta indica }\end{array}$ & $\begin{array}{l}\text { mango } \\
\text { coconut tree } \\
\text { papaya } \\
\text { teak } \\
\text { neem, nimtree, Indian lilac }\end{array}$ \\
\hline & Dominant ground species & $\begin{array}{l}\text { Commelinaceae } \\
\text { Euphorbiaceae } \\
\text { Nyctaginaceae } \\
\text { Phyllanthaceae } \\
\text { Poaceae }\end{array}$ & $\begin{array}{l}\text { Commelina benghalensis } \\
\text { Euphorbia sp. } \\
\text { Boerhavia diffusa } \\
\text { Phyllanthus amarus } \\
\text { Digitaria horizontalis }\end{array}$ & $\begin{array}{l}\text { benghal dayflower, tropical spiderwort } \\
\text { spurge } \\
\text { punarnava, red spiderling } \\
\text { gale of the wind, stonebreaker } \\
\text { Jamaican crabgrass }\end{array}$ \\
\hline & Crops & $\begin{array}{l}\text { Dioscoreaceae } \\
\text { Euphobiaceae } \\
\text { Fabaceae } \\
\text { Malvaceae } \\
\text { Pedaliaceae } \\
\text { Poaceae } \\
\text { Solanaceae }\end{array}$ & $\begin{array}{l}\text { Dioscorea sp. } \\
\text { Manihot esculenta } \\
\text { Arachis hypogaea } \\
\text { Vigna unguiculata } \\
\text { Gossypium sp. } \\
\text { Sesamum indicum } \\
\text { Zea mays } \\
\text { Sorghum sp. } \\
\text { Solanum lycopersicum }\end{array}$ & $\begin{array}{l}\text { yam } \\
\text { cassava } \\
\text { peanut } \\
\text { cowpea } \\
\text { cotton } \\
\text { sesame } \\
\text { maize } \\
\text { sorghum } \\
\text { tomato }\end{array}$ \\
\hline
\end{tabular}

Table 3. List of soil characteristics for each land cover type at the Savè site, including standard deviation.

\begin{tabular}{lrrrr}
\hline & Bare soil & Grassland & Maize field & Forest \\
\hline Clay $(<2 \mu \mathrm{m})(\%)$ & $5.13 \pm 0.63$ & $3.15 \pm 0.50$ & $4.40 \pm 0.35$ & $3.70 \pm 1.25$ \\
Fine silt $(2$ to $20 \mu \mathrm{m})(\%)$ & $5.13 \pm 0.96$ & $2.93 \pm 0.32$ & $4.13 \pm 1.00$ & $3.40 \pm 1.21$ \\
Coarse silt $(20$ to $50 \mu \mathrm{m})(\%)$ & $5.98 \pm 0.51$ & $4.78 \pm 0.66$ & $4.37 \pm 0.38$ & $4.67 \pm 1.05$ \\
Total sand $(50$ to $2000 \mu \mathrm{m})(\%)$ & $83.75 \pm 1.82$ & $89.20 \pm 0.71$ & $87.13 \pm 0.99$ & $88.20 \pm 3.50$ \\
\hline
\end{tabular}

longest dry period of the measurement campaign (Figs. 2 to 5).

As discussed in Appendix B and C, 30\% of individual fluxes used to calculate the daily averages are very low and not distinguishable from adsorption or desorption of $\mathrm{NH}_{3}$ on chamber walls. These very low fluxes are, however, meaningful and indicate that some periods of near-zero fluxes must be taken into account to represent the processes of exchange in these ecosystems.

To our knowledge, $\mathrm{NH}_{3}$ soil fluxes from West African wet savanna are not available in the scientific literature. In Delon et al. (2017) $\mathrm{NH}_{3}$ soil fluxes measured in Dahra $\left(15^{\circ} 24^{\prime} \mathrm{N} 15^{\circ} 25^{\prime} \mathrm{W}\right)$, Senegal, on a dry savanna ecosystem show low fluxes with a predominance of $\mathrm{NH}_{3}$ emis- sion: $1.3 \pm 1.1,-0.1 \pm 1.1$ and $0.7 \pm 0.5 \mathrm{ngN} \mathrm{m}^{-2} \mathrm{~s}^{-1}$ over three different measurement campaigns. However, Sutton et al. (2007) shows how pre-cut grassland is characterized by $\mathrm{NH}_{3}$ deposition, as in our study, in contrast to post-cut grassland, which is marked by $\mathrm{NH}_{3}$ emission. It is interesting to note that the literature provides up to about $700 \mathrm{ngN} \mathrm{m}^{-2} \mathrm{~s}^{-1}$ of $\mathrm{NH}_{3}$ emission for fertilized Zea mays fields (Walker et al., 2013), while at our study site $\mathrm{NH}_{3}$ deposition was recorded for the maize field, which is not treated with mineral fertilizer.

As for $\mathrm{NO}$ concentrations, $\mathrm{NH}_{3}$ concentrations are reported in Figs. 2 to 5. Daytime means of $\mathrm{NH}_{3}$ concentration vary from nearly 0 to $12.46 \mathrm{ppb}$ for all sites, and the average concentration is $4.42 \pm 3.23$ ppb during the whole campaign. 
Table 4. List of soil characteristics for each land cover type at the Savè site for each soil sampling day: carbon-to-nitrogen ratio (C/N), organic carbon $\left(\mathrm{g} \mathrm{kg}^{-1}\right)$, and total nitrogen $\left(\mathrm{g} \mathrm{kg}^{-1}\right)$. The accuracy for the $\mathrm{C} / \mathrm{N}$ ratio is $14 \%$. The measurement accuracy for organic carbon and total nitrogen is $14 \%$ and $13 \%$, respectively.

\begin{tabular}{lrrrr}
\hline Soil type & Date & C/N ratio & $\begin{array}{r}\text { Organic C } \\
\left(\mathrm{g} \mathrm{kg}^{-1}\right)\end{array}$ & $\begin{array}{r}\text { Total N } \\
\left(\mathrm{g} \mathrm{kg}^{-1}\right)\end{array}$ \\
\hline \multirow{3}{*}{ Bare soil } & 6 Jul 2016 & 14.90 & 24.28 & 1.63 \\
& 9 Jul 2016 & 12.20 & 10.47 & 0.86 \\
& 19 Jul 2016 & 12.30 & 15.05 & 1.22 \\
& 28 Jul 2016 & 9.50 & 19.30 & 2.04 \\
\hline \multirow{3}{*}{ Grassland } & 7 Jul 2016 & 15.20 & 5.78 & 0.38 \\
& 9 Jul 2016 & 16.00 & 7.36 & 0.46 \\
& 19 Jul 2016 & 14.90 & 7.16 & 0.48 \\
Maize & 28 Jul 2016 & 10.90 & 4.56 & 0.42 \\
\hline \multirow{5}{*}{ Forest } & 9 Jul 2016 & 14.80 & 17.33 & 1.17 \\
& 19 Jul 2016 & 16.40 & 13.08 & 0.8 \\
& 28 Jul 2016 & 11.80 & 11.83 & 1.00 \\
\hline & 6 Jul 2016 & 14.80 & 7.98 & 0.54 \\
& 28 Jul 2016 2016 & 11.90 & 9.62 & 0.81 \\
\end{tabular}

Table 5. List of soil $\mathrm{pH}$, ammonium concentrations $\left[\mathrm{NH}_{4}^{+}\right]\left(\mathrm{mg} \mathrm{kg}^{-1}\right)$, soil emission potential $\Gamma_{\mathrm{g}}$, and soil compensation point $\chi_{\mathrm{g}}(\mathrm{ppb})$ for each land cover type at the Savè site for each soil sampling day. The measurement accuracy for $\mathrm{pH}$ is $0.15 \mathrm{when} \mathrm{pH} \leq 7$ and $0.20 \mathrm{when}$ $\mathrm{pH}>7$. The accuracy for ammonium concentrations $\left[\mathrm{NH}_{4}^{+}\right]$, soil emission potential $\Gamma_{\mathrm{g}}$, and soil compensation point $\chi_{\mathrm{g}}$ is $25 \%$.

\begin{tabular}{lrrrrr}
\hline \multirow{2}{*}{ Soil type } & Date & $\mathrm{pH}$ & $\begin{array}{r}{\left[\mathrm{NH}_{4}^{+}\right]} \\
\left(\mathrm{mg} \mathrm{kg}^{-1}\right)\end{array}$ & $\begin{array}{r}\Gamma_{\mathrm{g}} \\
{\left[\mathrm{NH}_{4}^{+}\right] /\left[\mathrm{H}^{+}\right]}\end{array}$ & $\begin{array}{r}X_{\mathrm{g}} \\
(\mathrm{ppb})\end{array}$ \\
\hline \multirow{5}{*}{ Bare soil } & 6 Jul 2016 & 8.38 & 6.82 & 136334 & 1891 \\
& 9 Jul 2016 & 7.73 & 2.90 & 12978 & 134 \\
& 19 Jul 2016 & 8.46 & 6.63 & 159343 & 2188 \\
& 28 Jul 2016 & 8.34 & 8.01 & 146033 & 2215 \\
\hline \multirow{5}{*}{ Grassland } & 7 Jul 2016 & 7.15 & 1.96 & 2307 & 29 \\
& 9 Jul 2016 & 7.91 & 1.55 & 10499 & 108 \\
& 19 Jul 2016 & 7.52 & 2.28 & 6291 & 86 \\
Maize & 28 Jul 2016 & 6.51 & 2.30 & 620 & 9 \\
\hline \multirow{5}{*}{ Forest } & 9 Jul 2016 & 7.46 & 4.40 & 10575 & 109 \\
& 19 Jul 2016 & 7.61 & 14.74 & 50040 & 687 \\
& 28 Jul 2016 & 8.04 & 4.49 & 41027 & 622 \\
\hline & 6 Jul 2016 & 6.32 & 2.18 & 380 & 5 \\
& 29 Jul 2016 & 7.51 & 4.88 & 13159 & 181 \\
& 28 2016 & 7.37 & 11.47 & 22407 & 340 \\
\hline
\end{tabular}

The average $\mathrm{NH}_{3}$ concentration is $6.28 \pm 3.90 \mathrm{ppb}$ for bare soils, $3.28 \pm 1.79 \mathrm{ppb}$ for grassland, $4.36 \pm 3.99$ for the maize field, and $3.68 \pm 2.13 \mathrm{ppb}$ for forest (Table 6). The largest deposition fluxes are found on bare soils, where the largest concentrations are measured.

A multiple linear regression analysis was performed between daytime mean $\mathrm{NH}_{3}$ fluxes and the following variables: wind speed, soil temperature at $5 \mathrm{~cm}$, soil moisture at $5 \mathrm{~cm}$, soil heat flux, outgoing longwave radiation, and incoming shortwave radiation. This regression gives a weak but existing relationship, with $R^{2}=0.37(p$ value $=0.03)$. This correlation highlights the link between $\mathrm{NH}_{3}$ fluxes and relevant environmental parameters. However, the same considerations explained in Sect. 3.4 for $\mathrm{NO}$ emissions are also valid for the correlation between $\mathrm{NH}_{3}$ fluxes and meteorological variables.

According to the current parameterization of soil ammonia emission potential (Sect. 2.7), high values of $\mathrm{pH}$ and $\left[\mathrm{NH}_{4}^{+}\right]$ 
Table 6. List of average $\mathrm{NO}$ and $\mathrm{NH}_{3}$ fluxes $\left(\mathrm{ngN} \mathrm{m}^{-2} \mathrm{~s}^{-1}\right.$ ) and concentrations (ppb) for bare soil, grassland, maize field, forest sites, and all cover types.

\begin{tabular}{lrrrrr}
\hline & Bare soil & Grassland & Maize field & Forest & $\begin{array}{r}\text { Mean over all } \\
\text { land cover types }\end{array}$ \\
\hline NO fluxes $\left(\mathrm{ng} \mathrm{m}^{-2} \mathrm{~s}^{-1}\right)$ & $8.05 \pm 3.49$ & $2.82 \pm 3.46$ & $3.73 \pm 1.76$ & $2.87 \pm 1.49$ & $4.79 \pm 5.59$ \\
$\mathrm{NH}_{3}$ fluxes $\left(\mathrm{ng} \mathrm{m}^{-2} \mathrm{~s}^{-1}\right)$ & $-1.33 \pm 0.86$ & $-0.48 \pm 0.55$ & $-0.75 \pm 0.31$ & $-0.30 \pm 0.38$ & $-0.91 \pm 1.27$ \\
$\mathrm{NO}$ concentration $(\mathrm{ppb})$ & $2.97 \pm 1.49$ & $2.57 \pm 0.96$ & $2.55 \pm 0.83$ & $2.76 \pm 0.65$ & $2.70 \pm 1.03$ \\
$\mathrm{NH}_{3}$ concentration $(\mathrm{ppb})$ & $6.28 \pm 3.90$ & $3.28 \pm 1.79$ & $4.36 \pm 3.99$ & $3.68 \pm 2.13$ & $4.42 \pm 3.23$ \\
\hline
\end{tabular}

in the liquid phase will determine high values of $\Gamma_{\mathrm{g}}$, indicating that the soil has a high propensity to emit $\mathrm{NH}_{3}$. However, despite the high values of $\Gamma_{\mathrm{g}}$ recorded, our measurement site remains a net sink for $\mathrm{NH}_{3}$. The possible reasons for this are manifold. One explanation could be that soil particles on our site may have a high adsorption capacity, limiting the amount of soil gaseous $\mathrm{NH}_{3}$ concentrations (Neftel et al., 1998), and the largest part of the estimated ammonium content in the soil may not be in the liquid phase, but adsorbed by solid soil particles. In these conditions ammonium will not be available for gas exchange to open porosity and the atmosphere (Flechard et al., 2013). Another explanation could be given by the presence of a water film at the soil surface (linked to high air humidity at the site), which will increase the net deposition process. David et al. (2009) conclude from their measurements that the bare soil can be a significant source of $\mathrm{NH}_{3}$ only for a limited period and only when the cut vegetation is removed, but not if the soil surface remains covered by grass. Measurements in Ferrara et al. (2014) show other occurrences of high soil ammonia emission potential and $\mathrm{NH}_{3}$ deposition.

Our measurements were conducted without vegetation inside the chambers, but vegetation was present in the fields. It is important to mention that the role of vegetation in $\mathrm{NH}_{3}$ bidirectional fluxes is essential, especially during the wet season (time of the experiment) when deposition on the vegetation through stomata and cuticles dominates the exchange (during rain events, the cuticular resistance becomes small and cuticular deposition dominates) due to an increase in the deposition velocity of $\mathrm{NH}_{3}$ (consecutive to the humidity response of the surface) and a decrease in the canopy compensation point, sensitive to the surface temperature and the surface wetness (Wichink Kruit et al., 2007).

\subsection{Comparison of observed and modelled NO soil emissions}

We have compared observed daytime averaged (08:00 to 18:00 LT) soil NO emissions with those modelled by GEOSChem for the entire period of the campaign over the model grid box including the measurement site. The model grid box is positioned at latitude $8.0-8.25^{\circ} \mathrm{N}$ and longitude 2.19 $2.5^{\circ} \mathrm{E}$. The area of this grid box is $958 \mathrm{~km}^{2}$. The land cover type within this grid box is classified as "savanna (warm)" but the surrounding area also consists of "woody savanna", while the observations were taken over the four land cover types representative of the region: bare soil, grassland, maize field, and forest.

The model is able to reproduce mean air temperature $\left(25.3 \pm 0.7^{\circ} \mathrm{C}\right)$ and the main rain events. Soil emissions of NO are well simulated in magnitude. Simulated NO emissions are often higher than those recorded over the grassland areas; however, simulated NO emissions are often within the error bars of measurements (Fig. 6). The model uses land cover and vegetation types to simulate the highly variable land and vegetation cover of the observation site. For this reason we do not expect the model to reproduce the site-to-site variability of the measured soil fluxes, but to at least reproduce their average magnitude and behaviour. It appears that when the model is able to reproduce the length and the intensity of rain events, NO emissions are especially well simulated, e.g. the model is able to reproduce the longest rain period (from 20 to 26 July 2016) and the decrease in emissions at the end of the measurement campaign.

\subsection{Estimate of total NO soil emissions and $\mathrm{NH}_{3}$ deposition for Benin}

In order to give a tentative estimate of $\mathrm{NO}$ and $\mathrm{NH}_{3}$ soil fluxes for Benin we have used the land use-land cover map of Benin provided by the US Geographical Survey Atlas: Landscapes of West Africa - A Window on a Changing World (CILSS, 2016; Fig. 7a). The method of mapping land useland cover used in this atlas was based on Landsat imagery and expert visual interpretation. In particular, these maps provide an accurate indication of cropland distribution using visual interpretation. According to CILSS (2016) Benin's present-day (2013) land cover is mainly savanna at almost $60 \%$, followed by agricultural land at $31 \%$, while forest is only a small fraction under $1 \%$ (the rest of the surface is mainly gallery forest and, to a smaller extent, settlements). In the atlas (CILSS, 2016) bare soils are defined as surfaces that are bare even in the green and rainy season. For Benin, the amount of bare soil estimated by CILSS (2016) is very small, not big enough to appear on the atlas maps. We have multiplied average NO emissions measured at the Savè site 


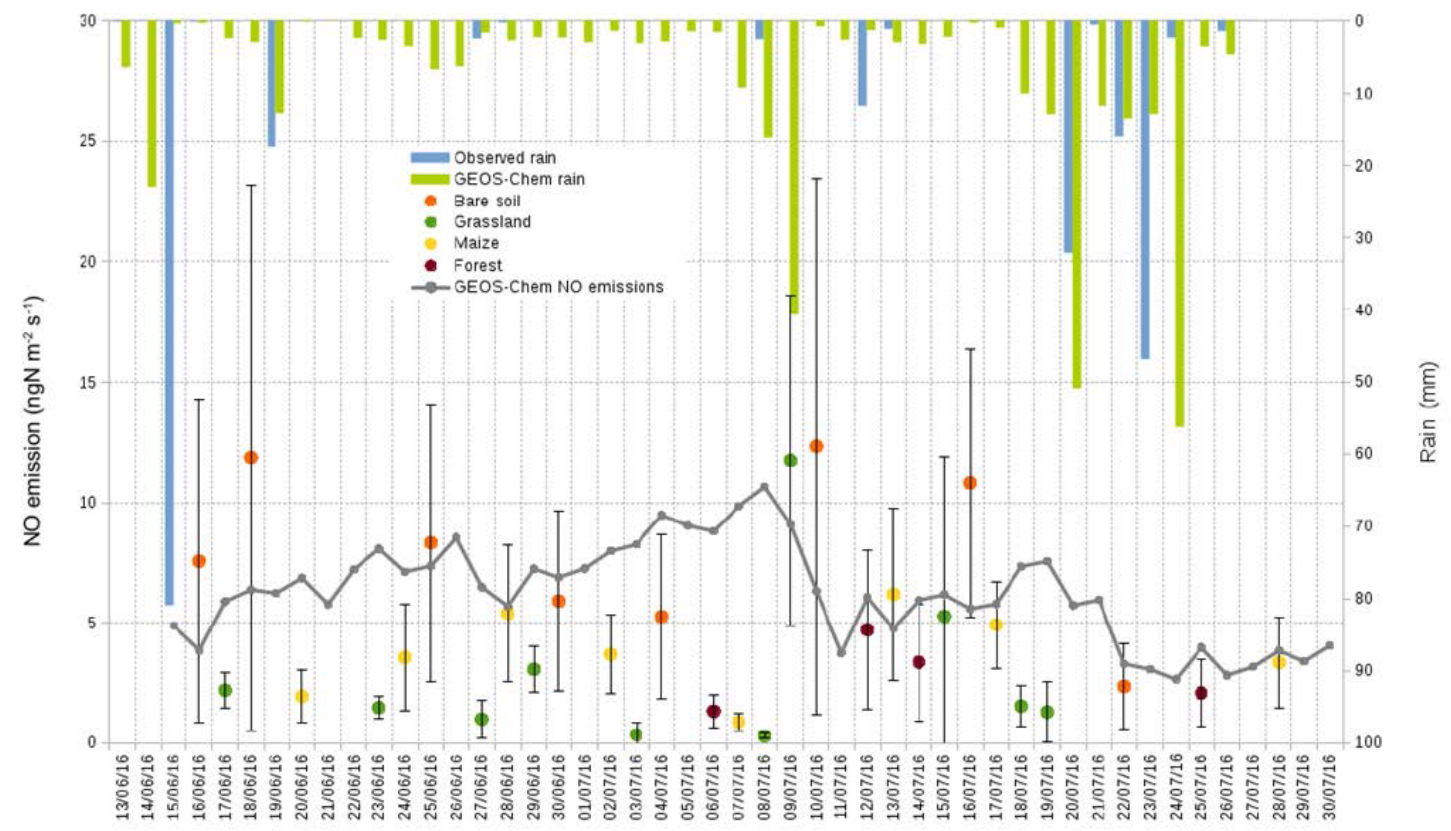

Figure 6. Nitric oxide emissions in $\mathrm{ngN} \mathrm{m}^{-2} \mathrm{~s}^{-1}$ measured over each land cover type (orange dot for bare soil, green for grassland, yellow for the maize field, and brown for forest) and simulated with GEOS-Chem, along with rainfall measured and modelled with GEOS-Chem. Soil NO emissions are daily averages between 08:00 and 18:00 LT.

for each land cover type by an estimate of the land cover area of each class given by the atlas. We have made some approximations: as the land use-land cover maps do not distinguish between shrub savanna, tree savanna, and wooded savanna, we have considered NO soil emissions from Savè's grassland savanna to be representative of the general savanna category in CILSS (2016). Moreover, the atlas has a crop category that does not distinguish the type of crop and we only have observations of NO soil emissions from an intercropped maize field. We have taken NO soil emissions from the maize field as representative of $\mathrm{NO}$ emissions from Benin's agricultural land, but other cultures are present in other parts of the country, e.g. oil palm plantations, where stronger fertilization could possibly determine higher NO soil emissions. This tentative calculation estimates Benin's NO soil emissions for the month of July (wet season) as $1.17 \pm 0.6 \mathrm{GgN}$ month $^{-1}$, i.e. $0.09 \%$ of the average global monthly NO soil emissions as given by Davidson et al. (1997).

We have also calculated Benin's total monthly NO soil emissions with GEOS-Chem by adding together the NO soil emissions from the grid boxes in which $50 \%$ or more of the box lies within Benin. Benin's total monthly NO soil emissions calculated with GEOS-Chem for the month of July are $1.44 \mathrm{GgN}_{\text {month }}{ }^{-1}$ and agree with the tentative calculation given above $\left(1.54 \pm 0.8 \mathrm{GgN} \mathrm{month}^{-1}\right)$. However, the land cover types covering Benin in GEOS-Chem differ from those in the US Geographical Survey Atlas (CILSS, 2016). In GEOS-Chem Benin is covered by $60.9 \%$ savanna, $31.4 \%$ woody savanna, $4.5 \%$ grassland, $1.3 \%$, mixed forest, and
$0.6 \%$ urban and built-up lands. Benin's total monthly NO soil emissions calculated with GEOS-Chem for the months of May and June are higher at 3.51 and $2.59 \mathrm{GgN} \mathrm{month}^{-1}$, respectively, given that those months are at the beginning of the wet season and are characterized by more predominant pulse emissions. Using the same method described above we have upscaled point measurements of $\mathrm{NH}_{3}$ fluxes with relevant land cover surfaces from CILSS (2016) and obtained total $\mathrm{NH}_{3}$ dry deposition for the month of July of

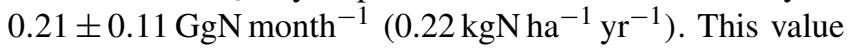
is about 10 times smaller than the estimation of $\mathrm{NH}_{3}$ dry deposition given in Adon et al. (2013) for the wet savanna site of Djougou (Benin, $9.7^{\circ} \mathrm{N}, 1.7^{\circ} \mathrm{E}$ ) for the month of July, which is around $2.5 \mathrm{kgN} \mathrm{ha}^{-1} \mathrm{yr}^{-1}$.

\section{Conclusions}

We provide soil flux measurements along with soil characteristics for a land cover type, savanna, that is considered to have large NO emissions (Davidson and Kingerlee, 1997) and for an area of the world, West Africa, with few observations. The aim of this study is to contribute to our knowledge of biogenic soil nitrogen exchanges, provide data for inventories, and model evaluation to improve air quality and climate modelling.

In situ measurements were made at a wet savanna site in central Benin from mid-June to the end of July 2016. Complementary to these exchange fluxes, soil $\mathrm{N}$ and $\mathrm{C}$ content, as well as soil $\mathrm{pH}$, soil moisture, soil temperature, and mete- 

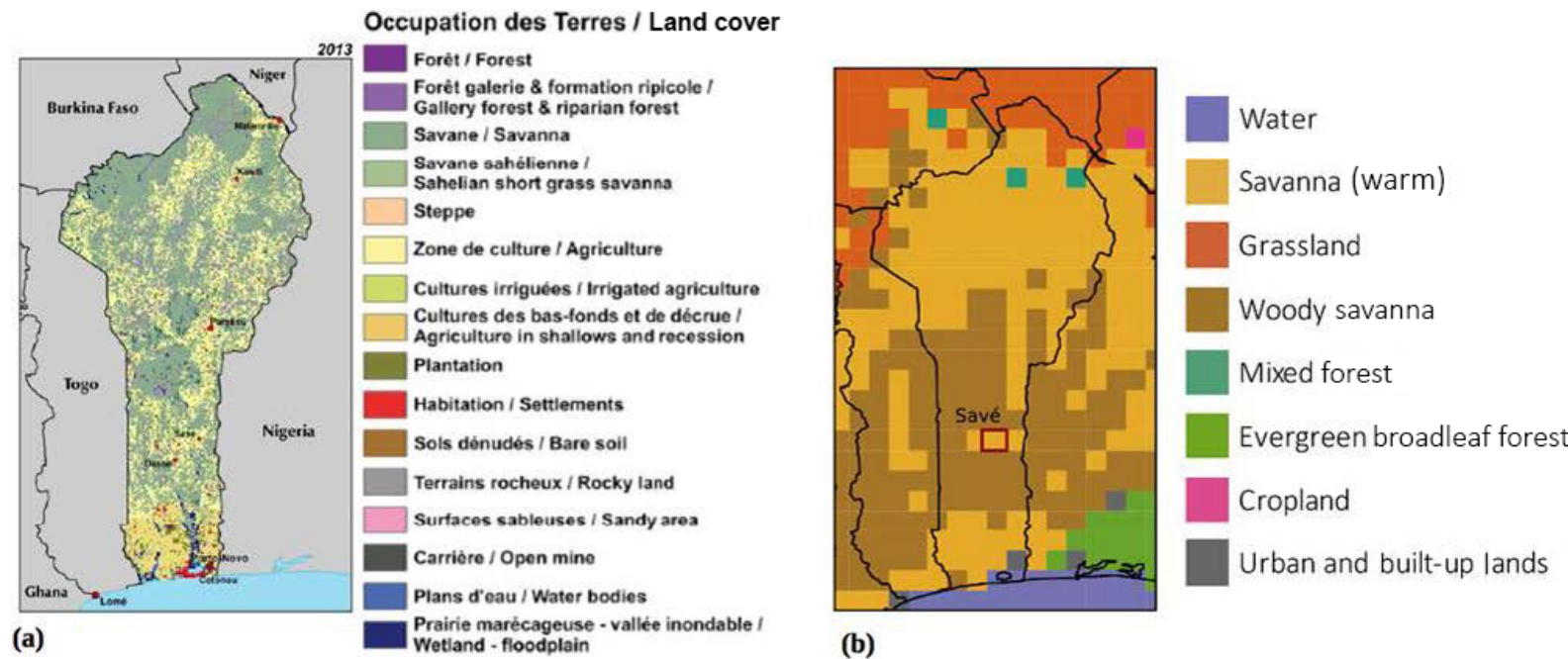

(b)

Figure 7. (a) Land cover map of Benin for 2013 from the US Geographical Survey Atlas: Landscapes of West Africa - A Window on a Changing World (CILSS, 2016). (b) Land cover map of Benin used in the GEOS-Chem simulation.

orological data were measured. Soil fluxes of $\mathrm{NO}$ and $\mathrm{NH}_{3}$ were measured over four different land cover types in order to give a tentative estimate of regional soil fluxes.

Given the set-up of the experiment, the known relationships between soil fluxes, soil temperature, and soil moisture were not reproduced. Rather than looking at the microbial and physical processes behind soil fluxes, we are able to provide observations that are representative of a bigger surface area and that represent the spatial variability of fluxes. However, we observe that while shorter rain events determine an increase in NO soil emissions, the longer rain event at the end of the campaign (20 to 24 July 2016) is accompanied by a decrease in NO soil emissions, in agreement with the fact that the relationship between NO soil emissions and soil moisture is not univocal. Soil emissions of NO increase until an optimum value of soil moisture is reached and then decrease (Oswald et al., 2013).

$\mathrm{NH}_{3}$ emissions measured in this study probably underestimate total $\mathrm{NH}_{3}$ emissions for the entire country, as possibly higher localized $\mathrm{NH}_{3}$ emissions are present in the south of the country where industrial-scale agriculture would probably deploy mineral $\mathrm{N}$ fertilization.

Soil NO emissions simulated by GEOS-Chem are in good agreement with the local observations taken at the site of Savè, providing a good baseline for simulating local atmospheric chemistry. Moreover, GEOS-Chem is also in good agreement with the tentative total monthly NO soil emission estimate for Benin for the month of July made with local observations in Savè and the US Geographical Survey Atlas (CILSS, 2016). All these elements contribute to improving our confidence in the results of modelling studies of local and regional air quality and climate over this region.

Agriculture is the first form of economic activity in Benin, occupying the majority of the active population. The most obvious recent change in land cover is the major expansion of agricultural land across most regions of Benin. Agricultural areas (including plantations and irrigated agriculture) progressed from $9.2 \%$ to $27.1 \%$ of the total country area between 1975 and 2013, improving food security. Oil palm trees are the main crop; oil palm farmland already covered most of the southern Terre de Barre plateau of Benin by 1975 and increased by about $28 \%$ over the following 38year period. A century or more ago, Benin was covered by dense, biologically diverse forest. Since then, Benin has lost nearly all of that forest cover; by 2013, 58\% of the 1975 forest cover had been lost, leaving only $0.2 \%$ of the country covered with dense forest. Savanna area has also decreased by $23 \%$ since 1975 , but it still remains the dominant land cover type in Benin and covers more than half of the country (CILSS, 2016).

More measurements of $\mathrm{NO}$ and $\mathrm{NH}_{3}$ exchanges between soil-vegetation-atmosphere in areas of Benin (or West Africa) affected by land use change could improve our estimate of the impact of biogenic soil emissions on air quality and climate, as biogenic soil fluxes influence, for example, the amount of aerosol and tropospheric $\mathrm{O}_{3}$, a greenhouse gas and pollutant, in the atmosphere. Management practices in agriculture affect biogenic soil emissions. Moreover, losing savanna to oil palm plantations or other crop would have different impacts on air quality, carbon budget, and climate than the conversion of forest into crop or oil palm plantation. Furthermore, oil palm plantations are generally closer to the coast and likely to be more influenced by anthropogenic emissions from industry and coastal cities (Knippertz et al., 2015a, b). Oil palm trees are also strong isoprene emitters. Isoprene emissions influence ozone concentration and the oxidizing capacity of the atmosphere, and it is a source of secondary organic aerosol, thus affecting local air quality and 
global climate. Large-scale land use change in the tropics specifically the conversion of tropical rainforest to oil palm plantations in Malaysia - was shown to cause changes in atmospheric composition and chemistry (Hewitt et al., 2009), indicating that the management of the emissions of reactive nitrogen species is essential to preventing damaging levels of ground-level ozone in those regions.

Data availability. All data are available at https://doi.org/10.6096/DACCIWA.1618 (Derrien et al., 2016). 


\section{Appendix A}

The dilution uncertainty is calculated based on the uncertainties of standard concentration, standard flow, and dilution flow. The uncertainty of standard concentration is $5 \%$ for $\mathrm{NO}$ and $\mathrm{NO}_{2}$ and $2 \%$ for $\mathrm{NH}_{3}$. The maximum uncertainty of dilution flow is $1 \%$ of the plain scale $\left(10 \mathrm{~L} \mathrm{~min}^{-1}\right)$ for the three standards divided by the flow used in the diluter (3.2 $\mathrm{L} \mathrm{min}^{-1}$ maximum), which gives $0.1 / 3.2=3.1 \%$. The uncertainty of standard flow is $1 \%$ of the plain-scale standard flow $\left(50 \mathrm{~mL} \mathrm{~min}^{-1}\right)$ divided by the standard flow used to obtain the needed concentration ( $50 \mathrm{ppb}$ for $\mathrm{NO}$ or $30 \mathrm{ppb}$ for $\mathrm{NH}_{3}$ ).

Standard flow: (needed concentration / standard concentration)*dilution flow.

- For NO, dilution flow is $3.2 \mathrm{~L} \mathrm{~min}^{-1}$, needed concentration is $50 \mathrm{ppb}$, standard concentration is $8.73 \mathrm{ppm}$, and standard flow is $18.4 \mathrm{~mL} \mathrm{~min}^{-1}$. The uncertainty of the standard flow is calculated as $1 \% \times 50 / 18.4=2.71 \%$. The total uncertainty is therefore $5 \%+3.1 \%+2.7 \%=\mathbf{1 0 . 8} \%$.

- For $\mathrm{NO}_{2}$, dilution flow is $3.2 \mathrm{~L} \mathrm{~min}^{-1}$, needed concentration is $50 \mathrm{ppb}$, standard concentration $\mathrm{s}$ $9.28 \mathrm{ppm}$, and standard flow is $17.2 \mathrm{~mL} \mathrm{~min}^{-1}$. The uncertainty of the standard flow is calculated as $1 \% \times 50 / 17.2=2.9 \%$. The total uncertainty is therefore $5 \%+3.1 \%+2.9=\mathbf{1 1} \%$.

- For NH3, dilution flow is $3.2 \mathrm{~L} \mathrm{~min}^{-1}$, needed concentration is $30 \mathrm{ppb}$, standard concentration is $14.78 \mathrm{ppm}$, and standard flow is $6.5 \mathrm{~mL} \mathrm{~min}^{-1}$. The uncertainty of the standard flow is calculated as $1 \% \times 50 / 6.5=7.7 \%$. The total uncertainty is therefore $2 \%+3.1 \%+7.7 \%=\mathbf{1 2 . 8} \%$. 
Table B1. Measurements of $\mathrm{NH}_{3}$ concentrations (ppb) through the chamber (TC) or directly (D) to the analyser.

\begin{tabular}{lrrrr}
\hline $\begin{array}{l}\text { Temperature } \\
\left({ }^{\circ} \mathrm{C}\right)\end{array}$ & $\begin{array}{r}\text { Humidity } \\
(\%)\end{array}$ & $\begin{array}{r}\mathrm{TCH}] \\
{\left[\mathrm{NH}_{3}\right]}\end{array}$ & $\begin{array}{r}\text { Ratio } \\
{\left[\mathrm{NH}_{3}\right] \mathrm{TC} /} \\
{\left[\mathrm{NH}_{3}\right] \mathrm{D}}\end{array}$ \\
\hline 25 & 54 & $26.4 \pm 0.4$ & $25.9 \pm 0.5$ & 1.02 \\
27 & 49 & $9.0 \pm 0.8$ & $8.0 \pm 1.2$ & 1.12 \\
29 & 46 & $35.2 \pm 2.4$ & $36.0 \pm 1.4$ & 0.98 \\
28 & 46 & $25.6 \pm 0.7$ & $24.0 \pm 1.0$ & 1.07 \\
27 & 45 & $26.2 \pm 0.9$ & $27.4 \pm 0.9$ & 0.96 \\
28 & 46 & $23.4 \pm 0.3$ & $24.1 \pm 0.4$ & 0.97 \\
26 & 50 & $19.2 \pm 0.6$ & $18.4 \pm 0.8$ & 1.04 \\
\hline
\end{tabular}

\section{Appendix B}

We ran a laboratory experiment to verify that deposition on the walls of the Teflon chamber is negligible.

Ambient air concentrations were measured by the analyser inside the room where the analyser and the chamber were placed. Measurements of $\mathrm{NH}_{3}$ concentrations were made in ambient air with and without the Teflon chamber attached to the analyser. The Teflon chamber was placed on a Teflon frame, and they were sealed together with Teflon tape. Measurements of $\mathrm{NH}_{3}$ concentrations with the Teflon chamber attached to the analyser were followed by measurements without the chamber 30 to $60 \mathrm{~min}$ later. The two sets of measurements were made under similar conditions of temperature and humidity. Average values of $\mathrm{NH}_{3}$ concentrations were calculated for 10 to $30 \mathrm{~min}$ before and after connecting the chamber. Average $\mathrm{NH}_{3}$ concentrations during this time interval varied between 8 and $36 \mathrm{ppb}$, with a variation between $1.5 \%$ and $13 \%$ around the mean. The lowest $\mathrm{NH}_{3}$ concentrations correspond to air samples previously passed through charcoal and desiccant cartridges $\left(\mathrm{NO}\right.$ and $\mathrm{NO}_{2}$ zero air). Measured $\mathrm{NH}_{3}$ concentrations are reported in Table B1, along with temperature, humidity, and the ratio between average concentration with and without the Teflon chamber attached to the analyser.

This test was made at different times of the day on different days: air humidity varied between 46 and 54\%, temperature varied between 25 to $29^{\circ} \mathrm{C}$, and pressure varied between 1006 and $1008 \mathrm{hPa}$ (not reported).

Results show negligible variation between concentrations of air reaching the analyser via the chamber or going directly to the analyser. The average difference in concentration is $0.9 \mathrm{ppb}$ and should be considered as the detection limit for fluxes significantly different from zero (i.e. including potential effects of adsorption or desorption); $30 \%$ of the concentration differences are below $0.9 \mathrm{ppbv}$.

To verify if mixing the air in the chamber by using a fan would change the shape of the increase in concentration or the concentration itself in the chamber, a test was made with a syringe simulating the action of a fan (i.e. we have mixed
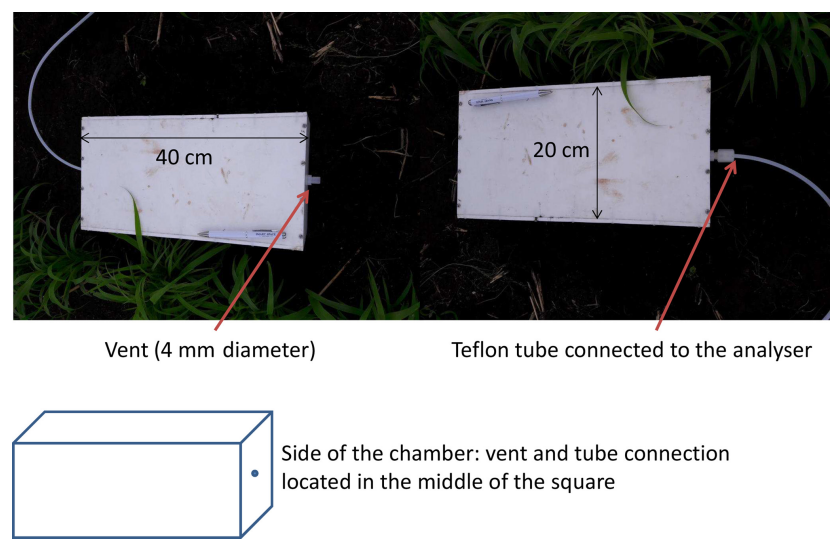

Figure B1. Description of the Teflon chamber.

the air inside the chamber by sucking and releasing the same air with a syringe through the small vent, while letting outside air enter the chamber through the vent as usual to ensure pressure equilibrium between outside and inside air). The comparison between a flux measurement with and without mixing gives similar slopes of the concentration increase (or decrease). 


\section{Appendix C}

$\mathrm{NH}_{3}$ concentration was recorded continuously inside the Teflon chamber (placed on Teflon material as in the tests summarized in Appendix A), and the chamber was cleaned successively with three different papers referred to as A, B, and $\mathrm{C}$. The concentration was recorded at least for $30 \mathrm{~min}$ between every cleaning. Table $\mathrm{C} 1$ summarizes the averaged concentrations (and standard deviations) for every period. Results show a variation of concentration when different papers are used, but this variation is not reproducible and is difficult to differentiate from a natural variation in the $\mathrm{NH}_{3}$ concentration in the room. As a matter of fact, the effect of cleaning on $\mathrm{NH}_{3}$ adsorption or desorption is not clear, but questions about the potential pollution of the chamber arise. Results in Table $\mathrm{C} 1$ may lead to the conclusion that if the difference in concentration during a flux measurement is below a certain threshold, it is not necessarily a flux from the ground but could be due to adsorption or desorption of $\mathrm{NH}_{3}$ by the chamber walls due to cleaning. Only low fluxes are concerned. Positive or negative fluxes below $0.55 \mathrm{ngN} \mathrm{m}^{-2} \mathrm{~s}^{-1}$ (corresponding to concentration differences less than $0.9 \mathrm{ppb}$ in the flux calculation, as defined in Appendix B) represent $30 \%$ of the 350 measured fluxes. If those low fluxes were removed from the database, the resulting average would be slightly larger in magnitude $(-1.1$ instead of $-0.9 \mathrm{ngN} \mathrm{m}^{-2} \mathrm{~s}^{-1}$ ). As a conclusion, these tests may help to warn the reader that caution must be kept for low $\mathrm{NH}_{3}$ fluxes because of possible pollution in the chamber.

Table C1. $30 \mathrm{~min}$ averaged concentrations in the Teflon chamber after cleaning with different dry papers.

\begin{tabular}{lrr}
\hline $\begin{array}{l}\text { Paper used } \\
\text { for cleaning }\end{array}$ & $\begin{array}{r}\text { 30 min average } \\
\text { (standard deviation) in ppb }\end{array}$ & $\begin{array}{r}\text { Difference between two } \\
\text { successive averages in ppb }\end{array}$ \\
\hline First day of test & & \\
\hline Before cleaning & $8.13 \pm 0.58$ & -0.69 \\
A & $7.43 \pm 0.47$ & 1.12 \\
B & $8.55 \pm 0.79$ & 1.18 \\
C & $9.73 \pm 0.81$ & 0.02 \\
B & $9.75 \pm 0.88$ & \\
\hline Second day of test & & 0.42 \\
\hline B & $16.35 \pm 0.92$ & 0.53 \\
C & $16.77 \pm 0.60$ & 1.64 \\
A & $17.30 \pm 0.76$ & 0.02 \\
A & $18.94 \pm 0.72$ & -0.17 \\
B & $18.96 \pm 0.62$ & \\
C & $18.79 \pm 0.79$ & \\
\hline
\end{tabular}




\section{Appendix D}

Table D1. Temperature measured on the Teflon chamber and on the Teflon tube. These measurements were made after the field campaign in direct sunlight at 15:30 LT (local time). Measurements were made with a calibrated thermometer (HI 98509) with a stainless-steel probe $\left(-50 \rightarrow+150^{\circ} \mathrm{C}\right)$.

\begin{tabular}{lr}
\hline Location of the temperature measurement & Temperature $\left({ }^{\circ} \mathrm{C}\right)$ \\
\hline Air & 32.7 \\
Soil & 34.2 \\
Chamber: outside wall & 33.1 \\
Chamber: inside wall & 33.3 \\
Chamber: outside top & 33.8 \\
Tube: outside close to the chamber & 30.5 \\
Tube: outside close to the analyser & 30.3 \\
Tube: inside & 30.9 \\
\hline
\end{tabular}




\section{Appendix E}

$\mathrm{NO}$ and $\mathrm{NH}_{3}$ fluxes are calculated from the slope of their concentration increase (or decrease) in the chamber through time. Two examples are given in Fig. E1 to illustrate the larger instability of $\mathrm{NH}_{3}$ detection compared to $\mathrm{NO}$ detection due to the possible interaction of $\mathrm{NH}_{3}$ with chamber walls or particulate matter in the chamber.
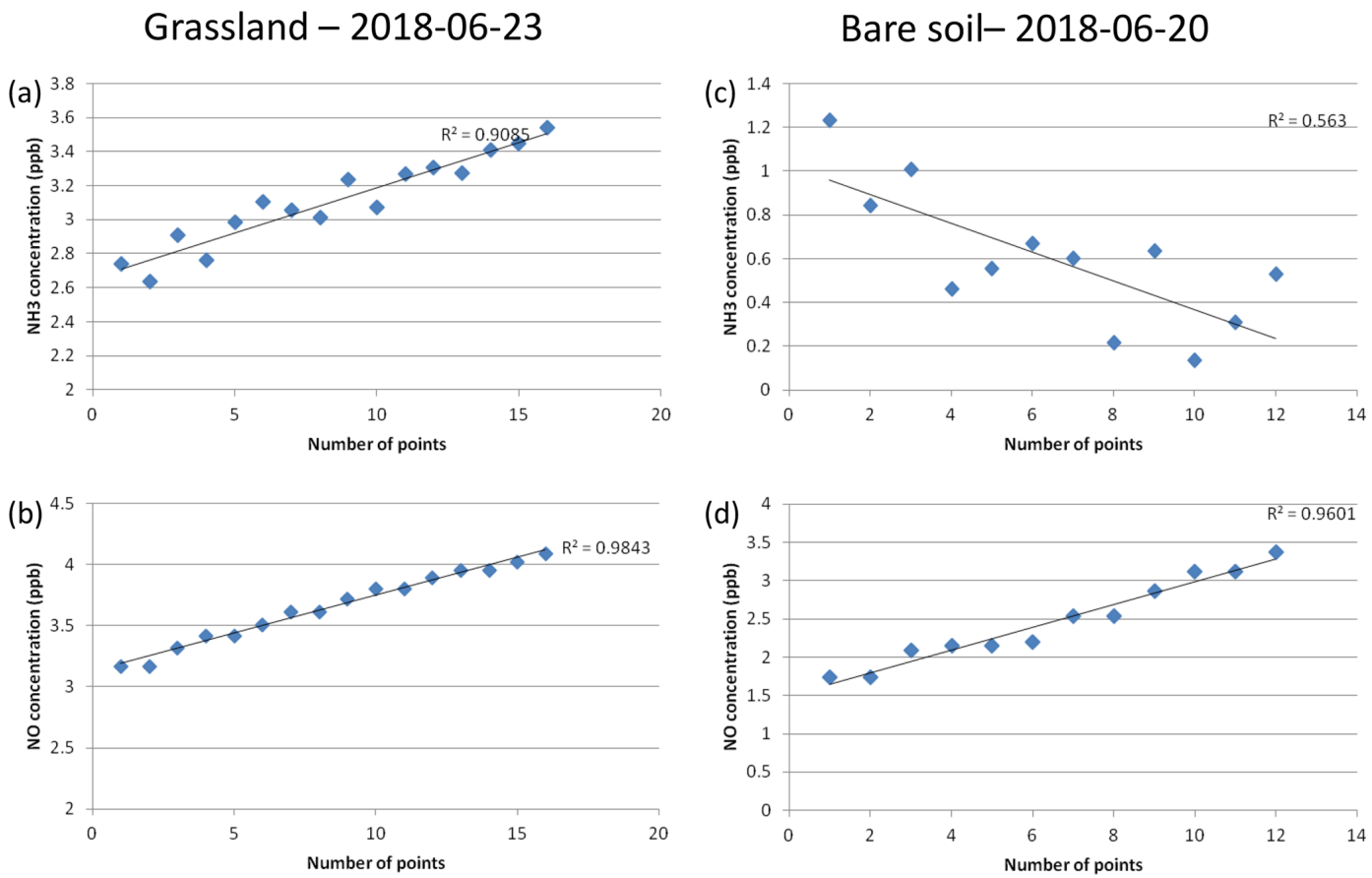

Figure E1. $\mathrm{NH}_{3}(\mathbf{a}, \mathbf{c})$ and $\mathrm{NO}$ concentration $(\mathbf{b}, \mathbf{d})$ variation with time (one point every $10 \mathrm{~s}$ ) inside the chamber on grassland (left) and bare soil (right) 
Author contributions. FP analysed the data collected during the measurement campaign and wrote the manuscript. CD planned the measurement campaign, prepared the instrumentation, optimised the measurement method, supervised the measurement campaign and performed the experiments in the Appendix section. CJ prepared the instrumentation and optimised the measurement method. PD, VHED, AVH, IRM and P-EB helped collecting the soil fluxes data during the measurement campaign. FL was responsible of the Savé supersite. SD collected the data from the meteorological station at the measurement site. EM and MJE performed the simulations with the GEOS-Chem model. All authors participated in the preparation of the manuscript.

Competing interests. The authors declare that they have no conflict of interest.

Special issue statement. This article is part of the special issue "Results of the project "Dynamics-aerosol-chemistry-cloud interactions in West Africa" (DACCIWA) (ACP/AMT inter-journal SI)". It is not associated with a conference.

Acknowledgements. The DACCIWA project received funding from the European Union Seventh Framework Programme (FP7/20072013) under grant agreement no. 603502. We also want thank the staff from NCAS (National Centre for Atmospheric Science), KIT (Karlsruhe Institute of Technology), and UPS (Université Paul Sabatier, Toulouse III) for helping to install the equipment, as well as the people from INRAB in Savè for allowing the equipment on their grounds.

Edited by: Sally E. Pusede

Reviewed by: five anonymous referees

\section{References}

Adon, M., Galy-Lacaux, C., Delon, C., Yoboue, V., Solmon, F., and Kaptue Tchuente, A. T.: Dry deposition of nitrogen compounds $\left(\mathrm{NO}_{2}, \mathrm{HNO}_{3}, \mathrm{NH}_{3}\right)$, sulfur dioxide and ozone in west and central African ecosystems using the inferential method, Atmos. Chem. Phys., 13, 11351-11374, https://doi.org/10.5194/acp-13-113512013, 2013.

Atkinson, R., Baulch, D. L., Cox, R. A., Crowley, J. N., Hampson, R. F., Hynes, R. G., Jenkin, M. E., Rossi, M. J., and Troe, J.: Evaluated kinetic and photochemical data for atmospheric chemistry: Volume $\mathrm{I}-$ gas phase reactions of $\mathrm{O}_{x}, \mathrm{HO}_{x}$, $\mathrm{NO}_{x}$ and $\mathrm{SO}_{x}$ species, Atmos. Chem. Phys., 4, 1461-1738, https://doi.org/10.5194/acp-4-1461-2004, 2004.

Bai, E., Li, S., Xu, W., Li, W., Dai, W., and Jiang, P.: A meta-analysis of experimental warming effects on terrestrial nitrogen pools and dynamics, New Phytol., 199, 441-451, https://doi.org/10.1111/nph.12252, 2013.

Barthès, B., Azontonde, A., Blanchart, E., Girardin, C., Villenave, C., Lesaint, S., Oliver, R., and Feller, C.: Effect of a legume cover crop (Mucuna pruriens var. utilis) on soil carbon in an Ultisol under maize cultivation in southern Benin, Soil Use Manage., 20, 231-239, 2004.

Bey, I., Jacob, D. J., Yantosca, R. M., Logan, J. A., Field, B. D., Fiore, A. M., Li, Q., Liu, H. Y., Mickley, L. J., and Schultz, M. G.: Global modeling of tropospheric chemistry with assimilated meteorology: Model description and evaluation, J. Geophys. Res., 106, 23073-23095, https://doi.org/10.1029/2001JD000807, 2001.

Bouwman, A. F., Boumans, L. J. M., and Batjes, N. H.: Emissions of $\mathrm{N}_{2} \mathrm{O}$ and $\mathrm{NO}$ from fertilized fields: summary of available measurement data, Global Biogeochem. Cy., 16, 1058, https://doi.org/10.1029/2001GB001811, 2002.

Brito, J., Freney, E., Dominutti, P., Borbon, A., Haslett, S. L., Batenburg, A. M., Colomb, A., Dupuy, R., Denjean, C., Burnet, F., Bourriane, T., Deroubaix, A., Sellegri, K., Borrmann, S., Coe, H., Flamant, C., Knippertz, P., and Schwarzenboeck, A.: Assessing the role of anthropogenic and biogenic sources on $\mathrm{PM}_{1}$ over southern West Africa using aircraft measurements, Atmos. Chem. Phys., 18, 757-772, https://doi.org/10.5194/acp-18-7572018, 2018.

Brooks, B., Bessardon, G., Smith, V., Groves, J., Sharpe, S., Kalthoff, N., Adler, B., Handwerker, J., Kohler, M., Kunka, N., Tan, N., Wieser, A., Lohou, F., Bezombes, Y., Bret, G., Delon, C., Derrien, S., Dione, C., Durand, P., Etienne, P., Gabella, O., Jambert, C., Leclercq, J., Lothon, M., Medina, P., Pedruzo, X., Reinares, I., Jegede, G., Ayoola, M., Sunmonu, L., Ajao, A., Abiye, O., Ajileye, O., Aryee, J., Fosu-Amankwah, K., CayleAethelhard, F., Atiah, W. A., Amekudzi, L., and Danuor, S.: A new high-quality dataset of the southern West African atmospheric boundary layer diurnal cycle during the Monsoon season, Sci. Data, in preparation, 2019.

Cassity-Duffey, K., Cabrera, M., and Rema, J.: Ammonia Volatilization from Broiler Litter: Effect of Soil Water Content and Humidity, Soil Sci. Soc. Am. J., 79, 543-550, 2014.

CILSS: Landscapes of West Africa - A Window on a Changing World, U.S. Geological Survey, EROS, 47914 252nd St, Garretson, SD 57030, UNITED STATES, 2016.

David, M., Loubet, B., Cellier, P., Mattsson, M., Schjoerring, J. K., Nemitz, E., Roche, R., Riedo, M., and Sutton, M. A.: Ammonia sources and sinks in an intensively managed grassland canopy, Biogeosciences, 6, 1903-1915, https://doi.org/10.5194/bg-61903-2009, 2009.

Davidson, E. A.: Fluxes of nitrous oxide and nitric oxide from terrestrial ecosystems, in: Microbial Production and Consumption of Greenhouse Gases: Methane, Nitrogen Oxides and Halomethanes, edited by: Rogers, J. E. and Whitman, W. B., American Society for Microbiology, Washington, 219-235, 1991.

Davidson, E. A. and Kingerlee, W.: A global inventory of nitric oxide emissions from soils, Nutr. Cycl. Agroecosys., 48, 37-50, 1997.

Delon, C., Galy-Lacaux, C., Adon, M., Liousse, C., Serça, D., Diop, B., and Akpo, A.: Nitrogen compounds emission and deposition in West African ecosystems: comparison between wet and dry savanna, Biogeosciences, 9, 385-402, https://doi.org/10.5194/bg9-385-2012, 2012.

Delon, C., Galy-Lacaux, C., Serça, D., Loubet, B., Camara, N., Gardrat, E., Saneh, I., Fensholt, R., Tagesson, T., Le Dantec, V., Sambou, B., Diop, C., and Mougin, E.: Soil and vegetation- 
atmosphere exchange of $\mathrm{NO}, \mathrm{NH}_{3}$, and $\mathrm{N}_{2} \mathrm{O}$ from field measurements in a semi arid grazed ecosystem in Senegal, Atmos. Environ., 156, 36-51, 2017.

Derrien, S., Bezombes, Y., Bret, G., Gabella, O., Jarnot, C., Medina, P., Pique, E., Delon, C., Dione, C., Campistron, B., Durand, P., Jambert, C., Lohou, F., Lothon, M., Pacifico, F., and Meyerfeld, Y.: DACCIWA field campaign, Savè super-site, UPS instrumentation, SEDOO OMP, Data set, https://doi.org/10.6096/DACCIWA.1618, 2016.

Dick, J., Skiba, U., Munro, R., and Deans, D.: Effect of N-fixing and non $\mathrm{N}$-fixing trees and crops on $\mathrm{NO}$ and $\mathrm{N}_{2} \mathrm{O}$ emissions from Senegalese soils, J. Biogeogr., 33, 416-423, 2006.

EC-JRC/PBL: Emission Database for Global Atmospheric Research (EDGAR), release version 4.2. European Commission, Joint Research Centre (JRC)/Netherlands Environmental Assessment Agency (PBL), available at: http://edgar.jrc.ec.europa.eu (last access: 15 February 2019), 2011.

Ellis, R. A., Murphy, J. G., Pattey, E., van Haarlem, R., O'Brien, J. M., and Herndon, S. C.: Characterizing a Quantum Cascade Tunable Infrared Laser Differential Absorption Spectrometer (QC-TILDAS) for measurements of atmospheric ammonia, Atmos. Meas. Tech., 3, 397-406, https://doi.org/10.5194/amt-3397-2010, 2010.

Ferrara, R. M., Loubet, B., Decuq, C., Palumbo, A. D., Di Tommasi, P., Magliulo, V., Masson, S., Personne, E., Cellier, P., and Rana, G.: Ammonia volatilisation following urea fertilisation in an irrigated sorghum crop in Italy, Agr. Forest Meteorol., 195-196, 179-191, 2014.

Flechard, C. R., Massad, R.-S., Loubet, B., Personne, E., Simpson, D., Bash, J. O., Cooter, E. J., Nemitz, E., and Sutton, M. A.: Advances in understanding, models and parameterizations of biosphere-atmosphere ammonia exchange, Biogeosciences, 10, 5183-5225, https://doi.org/10.5194/bg-10-5183-2013, 2013.

Fuzzi, S., Baltensperger, U., Carslaw, K., Decesari, S., Denier van der Gon, H., Facchini, M. C., Fowler, D., Koren, I., Langford, B., Lohmann, U., Nemitz, E., Pandis, S., Riipinen, I., Rudich, Y., Schaap, M., Slowik, J. G., Spracklen, D. V., Vignati, E., Wild, M., Williams, M., and Gilardoni, S.: Particulate matter, air quality and climate: lessons learned and future needs, Atmos. Chem. Phys., 15, 8217-8299, https://doi.org/10.5194/acp15-8217-2015, 2015.

Ganzeveld, L. N., Lelieveld, J., Dentener, F. J., Krol, M. C., Bouwman, A. J., and Roelofs, G.-J.: Global soil-biogenic $\mathrm{NO}_{x}$ emissions and the role of canopy processes, J. Geophys. Res., 107, 4298, https://doi.org/10.1029/2001JD001289, 2002.

Giglio, L., Randerson, J. T., and van der Werf, G. R.: Analysis of daily, monthly, and annual burned area using the fourth-generation global fire emissions database (GFED4), J. Geophys. Res.-Biogeosci., 118, 317-328, https://doi.org/10.1002/jgrg.20042, 2013.

Grote, R., Lehmann, E., Brümmer, C., Brüggemann, N., Szarzynski, J., and Kunstmann, H.: Modelling and observation of biosphereeatmosphere interactions in natural savannah in Burkina Faso, West Africa, Phys. Chem. Earth, 34, 251-260, 2009.

Guenther, A. B., Jiang, X., Heald, C. L., Sakulyanontvittaya, T., Duhl, T., Emmons, L. K., and Wang, X.: The Model of Emissions of Gases and Aerosols from Nature version 2.1 (MEGAN2.1): an extended and updated framework for mod- eling biogenic emissions, Geosci. Model Dev., 5, 1471-1492, https://doi.org/10.5194/gmd-5-1471-2012, 2012.

Handwerker, J., Scheer, S., and Gamer, T.: DACCIWA field campaign, Savè super-site, Cloud and precipitation; SEDOO OMP, Data set, https://doi.org/10.6096/DACCIWA.1686, 2016.

Hartley, A. E. and Schlesinger, W. H.: Environmental controls on nitric oxide emission from northern Chihuahuan desert soils, Biogeochemistry, 50, 279-300, 2000.

Hewitt, C. N., MacKenzie, A. R., Di Carlo, P., Di Marco, C. F., Dorsey, J. R., Evans, M., Fowler, D., Gallagher, M. W., Hopkins, J. R., Jones, C. E., Langford, B., Lee, J. D., Lewis, A. C., Lim, S. F., McQuaid, J., Misztal, P., Moller, S. J., Monks, P. S., Nemitz, E., Oram, D. E., Owen, S. M., Phillips, G. J., Pugh, T. A. M., Pyle, J. A., Reeves, C. E., Ryder, J., Siong, J., Skiba, U., and Stewart, D. J.: Nitrogen Management Is Essential to Prevent Tropical Oil Palm Plantations from Causing Ground-Level Ozone Pollution, P. Natl. Acad. Sci. USA, 106, 18447-18451, 2009.

Hudman, R. C., Russell, A. R., Valin, L. C., and Cohen, R. C.: Interannual variability in soil nitric oxide emissions over the United States as viewed from space, Atmos. Chem. Phys., 10, 9943 9952, https://doi.org/10.5194/acp-10-9943-2010, 2010.

Hudman, R. C., Moore, N. E., Mebust, A. K., Martin, R. V., Russell, A. R., Valin, L. C., and Cohen, R. C.: Steps towards a mechanistic model of global soil nitric oxide emissions: implementation and space based-constraints, Atmos. Chem. Phys., 12, 7779-7795, https://doi.org/10.5194/acp-12-7779-2012, 2012.

IPCC: Climate Change 2007: The Physical Science Basis, Contribution of Working Group I to the Fourth Assessment Report of the Intergovernmental Panel on Climate Change, edited by: Solomon, S., Qin, D., Manning, M., Chen, Z., Marquis, M., Averyt, K. B., Tignor, M., and Miller, H. L., Cambridge University Press, Cambridge, UK and New York, USA, 2007.

Junhong, B., Gao, H., Deng, W., Yang, Z., Cui, B., and Xiao, R.: Nitrification potential of marsh soils from two natural salinealkaline wetlands, Biol. Fertil. Soils, 46, 525-529, 2010.

Kalthoff, N., Lohou, F., Brooks, B., Jegede, G., Adler, B., Babić, K., Dione, C., Ajao, A., Amekudzi, L. K., Aryee, J. N. A., Ayoola, M., Bessardon, G., Danuor, S. K., Handwerker, J., Kohler, M., Lothon, M., Pedruzo-Bagazgoitia, X., Smith, V., Sunmonu, L., Wieser, A., Fink, A. H., and Knippertz, P.: An overview of the diurnal cycle of the atmospheric boundary layer during the West African monsoon season: results from the 2016 observational campaign, Atmos. Chem. Phys., 18, 2913-2928, https://doi.org/10.5194/acp-18-2913-2018, 2018.

Kohler, M., Kalthoff, N., Seringer, J., and Kraut, S.: DACCIWA field campaign, Savè super-site, Surface measurements; SEDOO OMP, Data set, https://doi.org/10.6096/DACCIWA.1690, 2016.

Knippertz, P., Coe, H., Chiu, J. C., Evans, M. J., Fink, A. H., Kalthoff, N., Liousse, C., Mari, C., Allan, R. P., Brooks, B., Danour, S., Flamant, C., Jegede, O. O., Lohou, F., and Marsham, J. H.: The DACCIWA project: Dynamics-aerosolchemistry-cloud interactions in West Africa, B. Am. Meteorol. Soc., 96, 1451-1460, https://doi.org/10.1175/BAMS-D-1400108.1, 2015a.

Knippertz, P., Evans, M. J., Field, P. R., Fink, A. H., Liousse, C., and Marsham, J. H.: The possible role of local air pollution in climate change in West Africa, Nat. Clim. Change, 5, 815-822, https://doi.org/10.1038/nclimate2727, 2015b. 
Knippertz, P., Fink, A. H., Deroubaix, A., Morris, E., Tocquer, F., Evans, M. J., Flamant, C., Gaetani, M., Lavaysse, C., Mari, C., Marsham, J. H., Meynadier, R., Affo-Dogo, A., Bahaga, T., Brosse, F., Deetz, K., Guebsi, R., Latifou, I., Maranan, M., Rosenberg, P. D., and Schlueter, A.: A meteorological and chemical overview of the DACCIWA field campaign in West Africa in June-July 2016, Atmos. Chem. Phys., 17, 10893-10918, https://doi.org/10.5194/acp-17-10893-2017, 2017.

Kristensen, L., Lenschow, D. H., Gurarie, D., and Jensen, N. O.: A simple model for the reactive species in the convective atmospheric boundary layer, Bound.-Lay. Meteorol., 134, 195-221, https://doi.org/10.1007/s10546-009-9443-x, 2010a.

Kristensen, L., Lenschow, D. H., Gurarie, D., and Jensen, N. O.: Erratum to: A Simple Model for the Vertical Transport of Reactive Species in the Convective Atmospheric Boundary Layer, Bound.Lay. Meteorol., 135, 181-183, https://doi.org/10.1007/s10546010-9473-4, 2010b.

Lata, J.-C., Degrange, V., Raynaud, X., Maron, P.-A., Lensis, R., and Abbadie, L.: Grass populations control nitrification in savanna soils, Funct. Ecol., 18, 605-611, 2004.

Laville, P., Lehuger, S., Loubet, B., Chaumartin, F., and Cellier, P.: Effect of management, climate and soil conditions on $\mathrm{N}_{2} \mathrm{O}$ and $\mathrm{NO}$ emissions from an arable crop rotation using high temporal resolution measurements, Agr. Forest Meteorol. 151, 228-240, 2011.

Le Roux, X., Abbadie, L., Lensi, R., and Serça, D.: Emission of nitrogen monoxide from African tropical ecosystems: control of emission by soil characteristics in humid and dry savannas of West Africa, J. Geophys. Res., 100, 23133-23142, 1995.

Loubet, B., Decuq, C., Personne, E., Massad, R. S., Flechard, C., Fanucci, O., Mascher, N., Gueudet, J.-C., Masson, S., Durand, B., Genermont, S., Fauvel, Y., and Cellier, P.: Investigating the stomatal, cuticular and soil ammonia fluxes over a growing tritical crop under high acidic loads, Biogeosciences, 9, 1537-1552, https://doi.org/10.5194/bg-9-1537-2012, 2012.

Massad, R.-S., Nemitz, E., and Sutton, M. A.: Review and parameterisation of bi-directional ammonia exchange between vegetation and the atmosphere, Atmos. Chem. Phys., 10, 10359-10386, https://doi.org/10.5194/acp-10-10359-2010, 2010.

McCalley, C. K. and Sparks, J. P.: Controls over nitric oxide and ammonia emissions from Mojave Desert soils, Oecologia, 156, 871-881, 2008.

Meixner, F. X. and Yang, W. X.: in: Dryland Ecohydrology, edited by: D'Odorico, P. and Porporato, A., Springer, Dordrecht, Biogenic Emissions of Nitric Oxide and Ditrous Oxide from Arid and Semi-arid Land, Dryland Ecohydrology, Kluwer Academic Publishers B.V, Dordrecht, The Netherlands, 23-46, 2006.

Michiels, B., Babatounde, S., Dahouda, M., Chabi, S. L. W., and Buldgen, A.: Botanical composition and nutritive value of forage consumed by sheep during the rainy season in a Sudano-guinean savanna (central Benin), Trop Grasslands, 34, 43-47, 2000.

Miller, A. E., Schimel, J. P., Meixner, T., Sickman, J. O., and Melack, J. M.: Episodic rewetting enhances carbon and nitrogen release from chaparral soils, Soil Biol. Biochem., 37, 2195-2204, 2005.

Neftel, A., Blatter, A., Gut, A., Högger, D., Meixnera, F., Ammann, C., and Nathaus, F. J.: $\mathrm{NH}_{3}$ soil and soil surface gas measurements in a triticale wheat field, Atmos. Environ., 32, 499-505, 1998.
Oswald, R., Behrendt, T., Ermel, M., Wu, D., Su, H., Cheng, Y., Breuninger, C., Moravek, A., Mougin, E., Delon, C., Loubet, B., Pommerening-Röser, A., Sörgel, M., Pöschl, U., Hoffmann, T., Andreae, M. O., Meixner, F. X., and Trebs, I.: HONO Emissions from Soil Bacteria as a Major Source of Atmospheric Reactive Nitrogen, Science, 341, 1233-1235, 2013.

Paillat, J.-M., Robin, P., Hassouna, M., and Leterme, P.: Predicting ammonia and carbon dioxide emissions from carbon and nitrogen biodegradability during animal waste composting, Atmos. Environ. 39, 6833-6842, 2005.

Pape, L., Ammann, C., Nyfeler-Brunner, A., Spirig, C., Hens, K., and Meixner, F. X.: An automated dynamic chamber system for surface exchange measurement of non-reactive and reactive trace gases of grassland ecosystems, Biogeosciences, 6, 405429, https://doi.org/10.5194/bg-6-405-2009, 2009.

Parsons, D. A. B., Scholes, M. C., and Levine, J. S.: Biogenic NO emissions from savanna soils as a function of fire regime, soil type, soil nitrogen and water status, J. Geophys. Res., 101, 23683-23688, 1996.

Pilegaard, K.: Processes regulating nitric oxide emissions from soils, Phil. Trans. R. Soc. B, 368, 20130126, https://doi.org/10.1098/rstb.2013.0126, 2013.

Säidou, A., Kuyper, T. W., Kossou, D. K., Tossou, R., and Richards, P.: Sustainable soil fertility management in Benin: learning from farmers, NJAS-WAGEN J. LIFE SC., 52-3/4, 349-369, 2004.

Santín C. and Doerr, S. H.: Fire effects on soils: the human dimension,Phil. Trans. R. Soc. B, 371, 20150171, https://doi.org/10.1098/rstb.2015.0171, 2016.

Sauren, H., van Hove, B., Tonk, W., Jalink, H., and Bicanic, D.: On the Adsorption Properties of Ammonia to Various Surfaces, in: Monitoring of Gaseous Pollutants by Tunable Diode Lasers, edited by: Grisar, R., Schmidtke, G., Tacke, M., and Restelli, G., Springer, Dordrecht, 1989.

Scholes, M. C., Scholes, R. J., Parsons, D., Martin, R., and Winstead, E.: $\mathrm{NO}$ and $\mathrm{N}_{2} \mathrm{O}$ emissions from savanna soils following the first rains, Nut. Cy. Agroecosys., 48, 115-122, 1997.

Serça, D., Delmas, R., Le Roux, X., Parsons, D. A. B., Scholes, M. C., Abbadie, L., Lensi, R., Ronce, O., and Labroue, L.: Comparison of nitrogen monoxide emissions from several African tropical ecosystems and influence of season and fire, Global Biogeochem. Cy., 12, 637-651, 1998.

Steinkamp, J., Ganzeveld, L. N., Wilcke, W., and Lawrence, M. G.: Influence of modelled soil biogenic NO emissions on related trace gases and the atmospheric oxidizing efficiency, Atmos. Chem. Phys., 9, 2663-2677, https://doi.org/10.5194/acp-92663-2009, 2009.

Sutton, M. A., Nemitz, E., Erisman, J. W., Beier, C., Butterbach Bahl, K., Cellier, C., de Vries, W., Cotrufo, F., Skiba, U., Di Marco, C., Jones, S., Laville, P., Soussana, J. F., Loubet, B., Twigg, M., Famulari, D., Whitehead, J., Gallagher, M. W., Neftel, A., Flechard, C., Herrmann, B., Calanca, P. L., Schjoerring, J. K., Daemmgen,U.,Horvath, L., Tang, Y. S., Emmett, B. A., Tietema, A., Peňuelas, J., Kesik, M., Brueggemann, N., Pilegaard, K., Vesala, T., Campbell, C. L., Olesen, J. E., Dragosits, U., Theobald, M. R., Levy, P., Mobbs, D. C., Milne, R., Viovy, N., Vuichard, N., Smith, J. U., Smith, P. E., Bergamaschi, P., Fowler, D., and Reis, S.: Challenges in quantifying biosphereatmosphere exchange of nitrogen species, Environ. Pollut., 150, 125-139, 2007. 
Sutton, M., Reis, S., and Baker, S. M. H.: Atmospheric Ammonia, detecting emission changes and environmental impacts. Results of an expert workshop under the convention of long range transboundary air pollution, Springer Edition, New York, ISBN 9781-4020-9120-9, 2009a.

Sutton, M. A., Nemitz, E., Milford, C., Campbell, C., Erisman, J. W., Hensen, A., Cellier, P., David, M., Loubet, B., Personne, E., Schjoerring, J. K., Mattsson, M., Dorsey, J. R., Gallagher, M. W., Horvath, L., Weidinger, T., Meszaros, R., Dämmgen, U., Neftel, A., Herrmann, B., Lehman, B. E., Flechard, C., and Burkhardt, J.: Dynamics of ammonia exchange with cut grassland: synthesis of results and conclusions of the GRAMINAE Integrated Experiment, Biogeosciences, 6, 2907-2934, https://doi.org/10.5194/bg6-2907-2009, 2009.

Tiquia, S. M. and Tam, N. F. Y.: Fate of nitrogen during composting of chicken litter, Environ. Pollut., 110, 535-541, 2000.

Vaittinen O., M. Metsala, S., Persijn, M., Vainio, L., and Halonen, L.: Adsorption of ammonia on treated stainless steel and polymer surfaces, Appl. Phys. B, 115, 185-196, https://doi.org/10.1007/s00340-013-5590-3, 2013.

Vanlauwe, B., Diels, J., Lyasse, O., Aihou, K., Iwuafor, E. N. O., Sanginga, N., Merckx, R., and Deckers, J.: Fertility status of soils of the derived savanna and northern guinea savanna and response to major plant nutrients, as influenced by soil type and land use management, Nutr. Cy. Agroecosys., 62, 139-150, 2002.

Walker, J. T., Jones, M. R., Bash, J. O., Myles, L., Meyers, T., Schwede, D., Herrick, J., Nemitz, E., and Robarge, W.: Processes of ammonia air-surface exchange in a fertilized Zea mays canopy, Biogeosciences, 10, 981-998, https://doi.org/10.5194/bg-10-981-2013, 2013.
Wentworth, G. R., Murphy, J. G., Gregoire, P. K., Cheyne, C. A. L., Tevlin, A. G., and Hems, R.: Soil-atmosphere exchange of ammonia in a non-fertilized grassland: measured emission potentials and inferred fluxes, Biogeosciences, 11, 5675-5686, https://doi.org/10.5194/bg-11-5675-2014, 2014.

Whitehead, J. D., Twigg, M., Famulari, D., Nemitz, E., Sutton, M. A., Gallagher, M. W., and Fowler, D.: Evaluation of laser absorption spectroscopic techniques for eddy covariance flux measurements of ammonia, Environ. Sci. Technol., 42, 2041-2046, 2008.

Wichink Kruit, R. J., van Pul, W. A. J., Otjes, R. P., Hofschreuder, P., Jacobs, A. F. G., and Holtslag, A. A. M.: Ammonia fluxes and derived canopy compensation points over non-fertilized agricultural grassland in the Netherlands using the new gradient ammonia - high accuracy - monitor (GRAHAM), Atmos. Environ., 41, 1275-1287, 2007.

Wieser, A., Adler, B., and Deny, B.: DACCIWA field campaign, Savè super-site, Thermodynamic data sets; SEDOO OMP, Data set, https://doi.org/10.6096/DACCIWA.1659, 2016.

Yienger, J. J. and Levy II, H.: Global inventory of soil-biogenic $\mathrm{NO}_{x}$ emissions, J. Geophys. Res., 100, 11447-11464, 1995.

Yokelson, R. J., Christian, T. J., Bertschi, I. T., and Hao, W. M.: Evaluation of adsorption effects on measurements of ammonia, acetic acid, and methanol, J. Geophys. Res., 108, 4649, https://doi.org/10.1029/2003JD003549, 2003. 